NBER WORKING PAPER SERIES

\title{
EXTERNALITIES IN INTERNATIONAL TAX ENFORCEMENT: THEORY AND EVIDENCE
}

\author{
Thomas R. Tørsløv \\ Ludvig S. Wier \\ Gabriel Zucman \\ Working Paper 26899 \\ http://www.nber.org/papers/w26899 \\ NATIONAL BUREAU OF ECONOMIC RESEARCH \\ 1050 Massachusetts Avenue \\ Cambridge, MA 02138 \\ March 2020
}

We thank the Danish Tax Administration for data access and many conversations, Alan Auerbach, Johannes Becker, David Bradbury, Richard Bolwijn, Iain Campbell, Kimberly Clausing, Alex Cobham, Mihir Desai, Michael Devereux, Fritz Foley, Maya Forstater, Teresa Fort, Jason Furman, Martin Hearson, Niels Johannesen, Petr Janský, Michael Keen, Edward Kleinbard, Claus Kreiner, Paul Krugman, Gian Maria Milesi-Ferretti, Pierre Moscovici, Casey Mulligan, Gaetan Nicodeme, Mitchell Petersen, Thomas Piketty, Nadine Riedel, Dani Rodrik, Emmanuel Saez, Antoinette Schoar, Juan Carlos Suárez Serrato, Amir Sufi, Felix Tintelnot, John Van Reenen, Margrethe Vestager, Eric Zwick, and numerous seminar and conference participants for helpful comments and reactions. Zucman acknowledges financial support from the FRIPRO program of the Research Council of Norway. The authors retain sole responsibility for the views expressed in this research, and they do not necessarily reflect the views of the National Bureau of Economic Research.

NBER working papers are circulated for discussion and comment purposes. They have not been peer-reviewed or been subject to the review by the NBER Board of Directors that accompanies official NBER publications.

(C) 2020 by Thomas R. Tørsløv, Ludvig S. Wier, and Gabriel Zucman. All rights reserved. Short sections of text, not to exceed two paragraphs, may be quoted without explicit permission provided that full credit, including (C) notice, is given to the source. 
Externalities in International Tax Enforcement: Theory and Evidence

Thomas R. Tørsløv, Ludvig S. Wier, and Gabriel Zucman

NBER Working Paper No. 26899

March 2020

JEL No. H25,H26,H87

\begin{abstract}
$\underline{\text { ABSTRACT }}$
We show that the fiscal authorities of high-tax countries can lack the incentives to combat profit shifting to tax havens. Instead, they have incentives to focus their enforcement efforts on relocating profits booked by multinationals in other high-tax countries, crowding out the enforcement on transactions that shift profits to tax havens, and reducing the global tax payments of multinational companies. This incentive problem can help explain why profit shifting to lowtax countries persists despite its tax revenue cost for high-tax countries. The predictions of our model are motivated and supported by the analysis of two new datasets: the universe of transfer price corrections conducted by the Danish tax authority, and new cross-country data on international tax enforcement. Both of these datasets shows that that tax authorities in high-tax countries focus their transfer pricing enforcement effort on correcting transactions with other high-tax countries rather than transactions involving tax havens.
\end{abstract}

Thomas R. Tørsløv

University of Copenhagen,

Øster Farimagsgade 5

DK-1353 Copenhagen

thomas.torslov@econ.ku.dk

Ludvig S. Wier

UC Berkeley

530 Evans Hall \#3880

Berkeley, CA 94720

ludvig.wier@econ.ku.dk
Gabriel Zucman

Department of Economics

University of California, Berkeley

530 Evans Hall, \#3880

Berkeley, CA 94720

and NBER

zucman@berkeley.edu 


\section{Introduction}

Multinational firms can avoid taxes by shifting profits from high-tax countries to low-tax countries. A number of studies suggest that this profit shifting causes substantial losses of tax revenue (Crivelli, de Mooij and Keen, 2015; Bolwijn et al., 2018; Clausing, 2016; Tørsløv et al., 2018). In principle, tax authorities in high-tax countries can attempt to reduce profit shifting by increasing the monitoring of intra-group transactions and enforcing more strongly the rules governing the pricing of these transactions.1 Moreover, many countries have general anti-avoidance provisions, according to which transactions that are undertaken with the primary goal of avoiding taxes are illegal. This legal framework is a potentially powerful tool to curb profit shifting to sparsely populated, zero-tax countries such as Bermuda where little real activity takes place. Why, despite the sizable revenue losses involved, does profit shifting nonetheless persist?

This paper provides a novel answer to this question by studying the incentives faced by tax authorities. We show theoretically that the fiscal authorities of high-tax countries can lack the incentives to combat profit shifting to tax havens. Instead, they have incentives to focus their enforcement efforts on relocating profits booked by multinationals in other high-tax countries, which crowds out the enforcement on transactions that shift profits to tax havens and does not increase the global tax payments of multinational companies. This incentive problem can help explain why profit shifting to low-tax countries persists, even when the legal framework (such as general anti-avoidance provisions) to curb it exists.

To understand the logic of the argument, take the case of Denmark, a country where the corporate tax rate is $22 \%$. One euro of profit re-located to Denmark by the Danish tax authority is worth the same to Denmark whether it comes from Sweden, where the corporate tax rate is also $22 \%$, or from Bermuda, where the corporate tax rate is $0 \%$. That is, the Danish tax authority does not internalize the externality of reducing the corporate tax base in the partner country. But it may be easier for the Danish tax authority to relocate one euro booked by a multinational company in Sweden, for two reasons. First, it is more likely to succeed, because firms are unlikely to spend much resources opposing this transfer price correction: for them, whether profits are booked in Denmark or Sweden makes little difference to their global tax bill, since the tax rates in Denmark and Sweden are the same. Second, if there is a dispute between Denmark and Sweden, it is likely to be settled relatively quickly through the dispute

\footnotetext{
${ }^{1}$ The general principle governing the pricing of intra-group transactions is that these transactions should be conducted at arm's length, that is, as if the subsidiaries trading goods, services, or assets internally were unrelated. See, e.g., Zucman (2014) for a description and history of these rules.
} 
resolution agreements in force among OECD countries and EU countries. The correction of transactions between Denmark and Sweden crowds out the correction of transactions between Denmark and low-tax countries. Such corrections are harder to make as firms spend more legal resources to defend their transfer pricing optimization, and take more time (due to a lack of cooperation with some tax havens). In this paper, we formalize this argument and make precise the conditions under which it is optimal for high-tax countries to focus their enforcement resources on relocating profits booked in other high-tax countries.

Our theoretical predictions are motivated and supported by two novel datasets analyzed for the first time in this paper. We first analyze the universe of transfer price corrections initiated by the Danish tax authority - confidential micro-data internal to the Danish administration to which we were granted access in the context of this research. We find that the vast majority of transfer price corrections (about 82\%) initiated by the Danish tax authorities involve other hightax countries. As Denmark has a moderate corporate tax rate (22\% in 2015), this finding implies that the majority of transfer price corrections initiated by Denmark involve countries with higher rates and ultimately lower the taxes paid by the targeted multinationals globally. According to our estimates, the combined transfer price enforcement efforts of the Danish authorities increased the Danish tax collection by $€ 315$ million per year on average over the years 2008, 2009 and 2015, but lowered tax collection abroad by $€ 333$ million. This result is at odds with the popular perception that the enforcement activities of tax authorities increase the taxes paid by multinationals. We furthermore go through Danish court cases and find that the likelihood of multinationals appealing a transfer price correction is $50 \%$ higher whenever the transfer price correction involves a tax haven - consistent with the model prediction of multinationals putting up a fight whenever a correction disfavors their global tax bill.

Second, we analyze data on tax disputes between tax authorities by drawing on a survey of tax authorities conducted by the audit firm EY, in which EY asked 26 major economies which countries were the main focus of their transfer price correction efforts. Consistent with our theory, the data show that the majority of high-tax countries enforcement effort are directed at other high-tax countries. These corrections typically do not increase the taxes paid by multinationals, but merely re-shuffle tax payments across high-tax places. From a global perspective, such corrections are welfare decreasing, since they consume resources without changing global tax payments. In effect, non-haven countries steal revenue from each other while letting tax havens flourish.

Our findings have policy implications. There is an ongoing international effort to facilitate 
dispute resolution settlement in transfer pricing cases between high-tax countries. Our results highlight a previously overlooked adverse effect of facilitating dispute resolution: making it easier for high-tax countries to correct each other incentivizes more transfer price corrections between high-tax countries and as a result crowds out tax haven cases. The easier it is for, say, the French tax authority to relocate profits booked in Germany, the less resources it may devote to chasing the profits shifted to Bermuda-potentially increasing shifting to low-tax locales. Similarly, current efforts to implement minimum taxation at a country-by-country basis e.g. through controlled foreign corporation (CFC) rules could further impact the incentives facing tax-authorities. Under current proposals of country-by-country minimum taxation income declared in a tax haven may in part be subject to taxation in a high-tax country, while income declared in another high-tax country will not be. Thus, going after intentional profit shifting to tax havens may produce less tax revenue to the tax authority than going after income currently declared in a high-tax country. This could exacerbate the existing incentive for tax authorities not to go after profits booked in tax havens and thus - in turn — exacerbate profit shifting. This result changes if the country-by-country minimum tax is sufficiently high, such that the incentive for firms to shift profits disappears.

Our results highlight an overlooked inefficiency in the current international tax system. The uncertainties involved in determining arm's-length prices are large enough that they can soak up substantial enforcement resources, even though the related enforcement initiatives do not increase global corporate tax payments. International organizations as a whole argue that a fundamental corporate tax reform is needed to curb firms intentional profit shifting to tax havens. A number of such proposals suggests to abandon the idea of transfer pricing entirely (E.g. through formula apportionment or destination-based-cash-flow taxation). This paper highlights another reason to pursue such reform — it may save public and corporate resources on wasteful inconsequential tax enforcement.

The paper proceeds as follows. Section 2 discusses the related literature. In Section 3 , we discuss the institutional background of international tax corrections. In Section 4, we turn to the data and study the patterns in transfer price corrections. Section 5 presents our benchmark theoretical model and Section 6 considers a number of extensions. We conclude in Section 7 where we discuss the implications of our results for policy. 


\section{Related Literature}

\subsection{Profit Shifting and Transfer Pricing}

A body of work suggests that multinationals shift profits to low-tax places to avoid taxation. Grubert and Mutti (1991) and Hines and Rice (1994) were the first to document the correlation between firm profitability and corporate tax rates at the country level. Since then, a number of studies have found that the relationship between firm profitability and tax rates is likely to be causal and primarily driven by profit shifting (see Heckemeyer and Overesch, 2013, and Dharmapala, 2014, for an overview). Recent research suggests that profit shifting is non-linear, with a greater sensitivity of reported profits to large tax rate differentials, i.e., relatively more profit shifting to very low-tax locales (Dowd et al. 2017, Liu et al. 2017, Wier 2020).

Using customs data, a series of studies find that firms deviate from the arm's-length principle when trading with affiliates in low-tax countries (e.g., Bernard et al. 2006, Clausing 2003, Cristea and Nguyen 2016, Davies et al. 2018, Liu et al. forthcoming, and Wier 2020). There is also evidence of tax-motivated manipulations of intra-group transactions prices for services (Hebous and Johannesen 2015). Finally, there is evidence of firms shifting profits to tax havens by shifting debt, intangible property, and risk (Huizinga et al. 2008a, 2008b; Becker et al. 2018). A number of studies estimate that the global loss of corporate tax revenue is sizable, of the order of $10 \%$ to $20 \%$ of global corporate tax revenue (Clausing 2016, Tørsløv et al. 2018, UNCTAD 2015). For comparison, Alvarez-Martinez et al. (2018) find that profit shifting between hightax countries is small, about a tenth of the tax revenue loss due to profit shifting to low-tax countries.

Our contribution to this literature is to provide a new explanation for why this profit shifting persists, despite the substantial tax revenue cost for high-tax countries.

\subsection{International Tax Enforcement}

Our paper is also related to the literature on tax enforcement. In the classical Allingham and Sandmo (1972) model, there is an exogenous audit rate and penalty for non-compliance. Firms deviate from the true arm's length price until the point where the marginal tax saving equals the marginal increase in the expected penalty. For an internal optimum to exist, it is assumed that the likelihood of an audit increases with the size of the transfer price deviation and/or that the penalty rises convexly with the transfer price deviation. The incentives of the tax authority are not taken into consideration. This framework, originally developed to 
study individual income tax evasion, does not capture some key features of international tax enforcement. Through interviews with practitioners, Becker and Davis (2014) document that transfer pricing cases rarely involve penalties (but merely corrections) and that the likelihood of audit is mainly driven by firm size. This is also the case in Denmark, where Danish State Auditors in fact criticized the tax authority for not applying penalties and ignoring smaller multinationals/transactions (DSA, 2014).

Becker and Davis (2014) propose an alternative theoretical model to analyze transfer price manipulation, in which multinationals are audited with certainty by high-tax countries and thus can only avoid taxes with their tacit acceptance. The equilibrium transfer price is the outcome of a negotiation game between a high-tax country's tax authority, a low-tax country's, and a firm. Like the Allingham-Sandmo model, the Becker and Davies (2014) model predicts we should only observe enforcement efforts that increase the global tax bill of multinationals. As we will see, however, in the data we observe many enforcement initiatives that do not. Our paper provides an explanation for this apparent puzzle.

Last, a number of papers provide theories of why profit shifting persists focusing on the idea that higher-tax countries might gain on balance from profit shifting (e.g., by lowering the effective marginal tax rate on especially mobile firms; see, e.g., Hong and Smart, 2010; Haufler et al., 2018). The tax authorities of high-tax countries might perceive that profit shifting and tangible capital mobility are strongly substitutable - with less shifting there would be more

outflows of tangible capital, with potentially adverse effects on wages and employment - and rationally choose to limit enforcement for that reason. In the public debate, however, few elected officials in high-tax countries seem to openly defend profit shifting; rather, the more widespread position seems to be that this phenomenon ought to be combated by tax authorities. Our paper analyzes why profit shifting can persist in the current international tax system even if there is a sincere political will to curb it.

\section{Institutional Background}

In this section we describe the institutional framework that governs the conduct of transfer price corrections.

\subsection{The Transfer Pricing Unit}

To ensure profits are taxed according to the prevailing internationally-agreed rules, tax authorities in high-tax countries routinely audit companies. This work is usually carried out by 
dedicated transfer pricing units operating inside tax authorities. Concretely, transfer pricing units can ask for transfer pricing documentation, i.e., detailed reports prepared by firms to justify their internal transactions. These reports are usually long and hence time-consuming to audit. With limited resources available, the tax authorities must prioritize which companies are asked to deliver transfer pricing documentation. This prioritization is guided by the data available to the tax authorities, which is often scarce. In the case of Denmark, it is based on a screening of their financial and tax return data. $\left.\right|^{2}$

After receiving the transfer pricing documentation, the transfer pricing unit checks that intra-group transactions are conducted at arm's length. When they consider it is not the case, they can ask multinationals to correct transactions. These corrections are usually referred to as "transfer price" corrections, even though the corrections go beyond transfer prices per se. All aspects of multinational activity are examined, including not only the transfer prices of goods and services, but also debt shifting, intra-group sales of intangibles, and potential abuses of double-tax treaties.

Unlike other form of tax enforcement, the enforcement of transfer prices is asymmetrical: it can only raise tax revenue. In the context of individual income tax audits, auditors investigate both over- and underpayment of taxes and hence audits can result in a reduction in taxes paid. This is not the case when it comes to transfer price enforcement, since each country tries to increase its own tax base. France, for example, audits French companies with the aim to correct transactions that are disadvantageous to France but ignores any findings that would result in a lowering of the French tax base. The same goes for other countries.

As stated by the OECD (2010, pp. 2), "transfer pricing is not an exact science." A variety of methods are used to determine the arm's-length price (cost-plus pricing, comparable unrelated transactions, comparable related transactions, profit splits, etc.). Moreover, in some cases (e.g., service payments such as royalties, purchases of intellectual property such as brands) the correct arm's-length price is not conceptually clear (Devereux and Vella, 2017). As a result there is some uncertainty involved in setting arm's-length prices, which implies that firms will at times be at odds with tax authorities even when they do not voluntarily engage in tax-minimization behavior.

To conduct a tax adjustment the tax authority must first argue that the arm's length principle has not been well applied by the multinational. Concretely, the authorities must be able to

\footnotetext{
${ }^{2}$ Source: DSA (2014) and conversations with the Danish Transfer Pricing Unit. Historically, $100-400$ firms have been asked to deliver documentation each year. Based on the transfer price documentation the tax authority may chose to conduct a transfer price correction. Historically, 50-100 corrections are conducted each year.
} 
point to specific transactions that would have been priced differently if they had been conducted at arm's length, i.e., by unrelated parties. The firm can appeal this correction, and the courts may overturn the decision.

Two points are worth noting here. First, there is an information and resource asymmetry between firms and tax authorities. Firms have a thorough understanding of their own business and are advised by transfer pricing specialists (both in house and in accounting firms). Globally, around 330,000 people work in transfer pricing, of which about one percent are employed by tax authorities (see Figure 1) $\mathrm{H}^{3}$ That is, for each person working in transfer pricing within tax authorities, there are about 100 working in the private sector. Intra-group transactions are not systematically monitored by tax authorities; rather, enforcement relies primarily on selfregulation, which comes at a sizable cost for the private sector. According to our estimates the private sector spent about $\$ 25$ billion on transfer pricing services in 2019.4

Second, tax authorities depend on the corresponding country's tax authority. If a tax authority considers conducting a transfer price correction it will reach out to the corresponding country's tax authority to obtain crucial information on the entity in scoped such as transactions through this entity with other foreign affiliates and non-affiliates. Say e.g. that a tax authority suspects that a coffee producer is selling its coffee to cheaply to a foreign affiliate in a tax haven and that this foreign affiliate is reselling the coffee at a much higher price - having the effect of shifting profits to the tax haven. In this example, the tax authority trying to prove its point relies on the tax haven to deliver information on the entity's price-setting in transactions not involving the country initiating the correction. The corresponding country can hence supply supplementary information about the firm this eases the process of conducting a transfer price correction. Contrary, if the corresponding tax authority is not cooperating, this complicates the process.

\subsection{Mutual Agreement Procedures}

If a tax authority unilaterally increases the profits of a firm operating in its jurisdiction without another tax authority lowering the profits of the same firm, profits may be double counted and double taxed. International agreements exist to ensure that an increase in the tax base of a

\footnotetext{
${ }^{3} 328,261$ is the number of individuals that LinkedIn highlights when searching "transfer pricing" under "people" (as of January 4, 2020). Spot checks confirm that LinkedIn correctly identifies individuals working with transfer pricing. The number of individuals working in government with transfer pricing is first identified by filtering the search by industry to "government adminstration" only (3,368 as of January 4, 2020 and corroborated by the head count in EY's Transfer Pricing Tax Authority Survey from 2014

${ }^{4}$ Here using the average base salary of a transfer pricing specialist $(\$ 74,000$ as of Jan 4,2020$)$ computed by Glassdoor https://www.glassdoor.com/Salaries/transfer-pricing-salary-SRCH_KO0,16.htm
} 
multinational in one country is offset by a corresponding reduction in another. The procedure is as follows. After a tax authority has decided on a transfer price correction, the targeted firm may ask the tax authority to enter into a Mutual Agreement Procedure with the partner country (or countries) where taxable income has presumably been overbooked. The tax authority that increased its own tax base must then approach the partner country (or countries) and ask them to reduce their tax base (i.e., in effect, to pay for the transfer price correction). If an agreement is reached, this procedure results in a relocation of taxable income across countries. If no agreement is reached, then taxable income increases in one country without any offsetting decrease elsewhere. Within the European Union, an agreement is almost guaranteed: a strict system - known as the Arbitrage Convention - is in place to ensure that disputes among EU countries are settled within two years. If the tax authorities do not come to terms in that time frame, an external panel is brought in to settle the case $5^{5}$ Worldwide more than $90 \%$ of mutual agreement procedures result in some form of agreement (either a corresponding reduction or withdrawal of initial claim) ${ }^{6}$

Since the end of the 1990s, there has been a push to advance mutual agreement procedures. The OECD has played a key role in this process through the 1996 OECD Model Tax Convention (article 25) and in 2014 through its Base Erosion and Profit Shifting (BEPS) initiative, whose action 14 seeks to "make dispute resolution mechanisms more effective." In parallel, the EU has enhanced dispute resolution through the EU Arbitration Convention and the EU joint transfer pricing forum. In this forum EU states are held accountable as to the ease and speed with which they facilitate dispute resolutions.

The push for facilitating mutual agreement procedures has dramatically lowered the length of procedures and increased the number of cases markedly — particularly in high-tax countries. The OECD has since 2006 collected statistics on the number of newly started and closed mutual agreement procedures by country. The number of cases has from 2006 to 2018 more than doubled; from 1036 initiated cases in 2006 to 2385 initiated cases in 2018.7 The push for making dispute settlement more efficient accelerated in 2016, when the OECD began implementing the BEPS project through the inclusive framework (consisting of 137 countries) were all countries

\footnotetext{
${ }^{5}$ Mutual agreement procedures should not be conflated with Advance Pricing Agreements (APA). By using APAs, companies can get a contractual agreement with tax authorities that the authorities will not contest a transaction at a later point. See Becker et al. (2014) for an analysis of advance pricing agreements. Our paper does not study advance pricing agreements.

${ }^{6}$ See OECD MAP statistics 2016-2018

${ }^{7}$ See OECD MAP Statistics (n.d.). Note that the increase in cases is likely larger as the numbers prior to OECD established guidelines in 2016 may double count cases (https://www.oecd.org/tax/dispute/ mutual-agreement-procedure-statistics.htm)
} 
taking part where required to improve dispute settlement mechanisms. This led to a dramatic decrease in the average time taken to settle disputes after 2016: from 40 months to less than 7 months.$^{8}$ The result was also an astounding 59\% increase in initiated mutual agreement procedures from 2016-18. This push was primarily driven by an increase of new cases in nontax havens who where the target in $87 \%$ of new procedures (see appendix Figure A3).

\section{An Empirical Analysis of Transfer Price Corrections}

In this section we analyze the universe of transfer price corrections in Denmark using a unique micro-dataset, and we study patterns in transfer price corrections internationally using a newly assembled macro dataset. We start by the Danish case before extending the analysis to other countries.

\subsection{The Universe of Transfer Price Corrections in Denmark}

For the purpose of this research, the Danish tax authority has given us access to internal confidential micro-data on the universe of transfer price corrections undertaken by the Danish tax authority for the years 2008 and 2014-15 (the only years for which comprehensive data is available). These corrections pertains to the transfer prices of goods and services, but also debt shifting, intra-group sales of intangibles, and potential abuses of double-tax treaties. This is the key data source for this paper, which includes the increase in the tax base demanded by the tax administration and the counterpart country targeted. The ultimate outcome of these corrections will be the result of whether the tax payer appeal to the courts or asks for a mutual agreement procedure (or both). To shed light on the ultimate outcome we additionally obtained data on the initiated court appeal cases for the years 2011-16 and the closed mutual agreement procedures 2008-15. These different data sources could, unfortunately, not be linked to provide a full end-to-end view of the transfer price corrections but do nonetheless show us a comprehensive picture of the full process.

Table 1 presents summary statistics of the Danish tax authority's transfer pricing corrections and compares the results to available macroeconomic estimates of profit shifting out of Denmark.

Macroeconomic estimates of profit shifting out of Denmark suggest that from 2012-2015, about $€ 2,2$ billion per annum were shifted on net out of Denmark to other countries, the equivalent of $6 \%$ of the Danish corporate tax base (Panel A, col. 1). Cols. 2 and 3 decompose

\footnotetext{
${ }^{8}$ See https://www.oecd.org/tax/dispute/mutual-agreement-procedure-statistics-2017.htm. Note that the the average time for cases after 2016 is truncated due to some cases being open still.
} 
this total into profits shifted out of Denmark to tax havens 9 in 2015 as estimated by Tørsl $\varnothing \mathrm{v}$ et al. (2018), and profits shifted out of Denmark to non non-haven countries in 2012 as estimated by Alvarez-Martinez et al. (2018). Alvarez-Martinez et al. (2018) estimate that Denmark attracts profits from non-haven countries, because of its moderately low corporate tax rate of $25 \%$ in 2012 (further reduced to 22\% in 2015). More precisely, Alvarez-Martinez et al. (2018) estimate that Denmark is a net recipient of $€ 455$ million from non-tax havens ( $€ 532$ million in profits shifted inwards minus $€ 77$ million in profits shifted outwards) in 2012 . These amounts are small, however, in comparison to the profits shifted out of Denmark to tax havens, which amount to about $€ 2,670$ million in 2015 according to Tørsløv et al. (2018) (col. 3).

Panel B presents summary statistics on the transfer price corrections conducted by the Danish tax authority. That is, tax adjustments made by the Danish tax authority that require the firm to report more income in Denmark. In 2008, 2014, and 2015 Denmark conducted in total 185 transfer pricing corrections, or 62 cases on average per year (col. 1). These corrections included a variety of topics such as internal debt, transfer of intellectual property, and the price of headquarter services 10 On average over 2008, 2009 and 2015, corrections amounted to $€ 1.5$ billion a year, the equivalent of about 4 percent of the Danish corporate tax base. This large amount is the result of 62 cases per year, meaning that the average case size is large (€24 million). Small cases are not prioritized due to the high costs of conducting a transfer price correction (DSA, 2014).

Our analysis of the Danish transfer pricing cases reveals two main findings.

First, the vast majority of transfer price corrections (about 75\%) initiated by the Danish tax authorities involve other high-tax countries. This fraction is larger (82\%) when cases are dollar-weighted. That is, only $18 \%$ (€266 million per year) of the profits relocated to Denmark by the Danish tax authorities come from correcting transactions involving tax havens (col. 4). This implies that the Danish authorities' enforcement initiatives bring back into the Danish tax net about $10 \%$ ( $€ 266$ million out of $€ 2,670$ million) of the amount of profits shifted out of Denmark to tax havens. Meanwhile, the Danish authorities manage to relocate large amounts of profits booked by firms in other high-tax countries, i.e., in countries where it is unlikely that

\footnotetext{
${ }^{9}$ The list of tax havens includes Belgium, Cyprus, Ireland, Netherlands, Hong Kong, Luxembourg, Malta, Marshall Islands, Puerto Rico, Switzerland, Singapore and all the small offshore financial centers listed in Table 1 of Lane and Milesi-Ferretti (2010): Andorra, Anguilla, Antigua and Barbuda, Aruba, The Bahamas, Bahrain, Barbados, Belize, Bermuda, the British Virgin Islands, the Cayman Islands, Gibraltar, Grenada, Guernsey, the Isle of Man, Jersey, Lebanon, Liecht- enstein, Macao, Mauritius, Monaco, the Netherlands Antilles, Panama, Samoa, Seychelles, St. Kitts and Nevis, St. Lucia, St. Vincent \& Grenadines, Turks and Caicos, Vanuatu.

${ }^{10}$ The Danish State Auditors released information on the composition of these cases in their report on transfer pricing from 2014. In terms of amounts, by far the most important type of correction involved intra-group sales of intangible assets, which accounted for more than $75 \%$ of tax adjustments (DSA, 2014).
} 
there is intentional outward profit shifting. The enforcement efforts of the Danish tax authority appear to raise Danish tax revenue primarily by correcting unintentional mistakes made by firms in their transactions with related parties in high-tax countries, rather than intentional profit shifting to low-tax locales.

Figure 2 provides a granular depiction of the Danish tax authority's transfer pricing enforcement activities, by showing the distribution of the tax differentials (Danish tax rate minus foreign country's tax rate) for the universe of cases pursued by the authority. As discussed in Section 2, a large literature documents the effect of statutory tax rate differentials on the pricing of intra-group goods and service transactions. On a priori grounds, we thus expect that transactions involving countries with lower corporate tax rates than Denmark should be overrepresented in the Danish tax authorities' enforcement efforts. Interestingly, however, we find that $80 \%$ of the transfer pricing cases initiated by Denmark involve countries with similar or higher tax rates than Denmark. The average tax differential (Danish tax rate minus counterpart country rate) is $-4.1 \%$ and statistically significant.

One potential concern with this result is that the bulk of firms related to Danish companies (parents, subsidiaries, or sister companies) might be located in high-tax countries. It is therefore useful to consider how the geographical distribution of the Danish tax authority's transfer pricing corrections would look like if audits were conducted randomly and the tax authority always found something when doing an audit.11 To construct this benchmark we use the ORBIS database from Bureau van Dijk, from which we can construct the distribution of tax differentials between all Danish multinational entities (parents or subsidiaries) and their foreign related parties. Because Denmark has a moderately low corporate tax rate (in the range of $22 \%-25 \%$ during the 20082015 period), the average tax differential between Denmark and the countries where related parties are located is negative $(-2.3 \%)$. Interestingly, however, the average tax differential for the cases pursued by the tax authority $(-4.1 \%)$ is smaller than the random tax differential ($2.3 \%$ ). In other words, the Danish tax authority targets transactions involving high-tax countries over-and-above the geography of intra-group links. We do a similar analysis relying on the total inward and outward FDI income and obtain very similar results (see Appendix figure A1).

The second result from our analysis is that overall, if fully realized, the transfer price corrections of the Danish tax authority have an overall slightly negative effect on the global tax bill of the targeted multinationals. By using statutory corporate tax rates (from KPMG), we can estimate the final net effect of the Danish authorities' transfer pricing enforcement effort

\footnotetext{
${ }^{11}$ Since the tax law can be hard to interpret and international tax enforcement efforts are asymmetric (they can only raise revenue), even random audits would result in extra tax collection.
} 
on the global tax bills of the targeted firms ${ }^{12}$ The result are reported in the Panel C of Table 1. The Danish transfer price corrections increased tax payments in Denmark by $€ 315$ million on average per year. But, if fully realized, they reduced tax payments abroad by $€ 333$ million, implying a reduction in the global tax bill of the targeted multinationals of $€ 19$ million ${ }^{13}$ In comparison to the Danish tax base, the net impact is essentially zero, but the gross increase in Danish tax revenue is of course still very real. That is, Danish transfer price corrections are not impacted by their tax externality abroad.

The ultimate impact of the initial tax adjustments on the tax bill of the multinationals operating in Denmark depends on the outcome of the mutual agreement procedure (if a procedure is started) and whether the correction is upheld in court (if the adjustment is appealed). Mutual agreement procedures and court cases are lengthy affairs and the Danish tax authority has not attempted to track the cases from start until final outcome. From interviews and internal project plans we found that transfer price correction are very rarely overruled in court, but that mutual agreement procedures usually result in a $30 \%$ reduction in the initial claim. To investigate the final outcome of transfer price corrections, we received data on completed (non-zero) mutual agreement procedures for the period 2008-2015. Due to the lengthy mutual agreement procedures, these completed cases are for the most part likely initiated before the beginning of our data set on transfer price corrections. Note that this data cannot be directly interpreted as the final outcome of all initiated transfer price corrections, as firms could potentially repeal the correction in court and firms may decide not to initiate a mutual agreement procedure following a correction (this will in particular be the case if the taxes paid in the corresponding country are negligible). The distribution of completed mutual agreement procedure cases is plotted in Appendix Figure A2. We see that in the case of completed mutual agreement procedures more than $90 \%$ of these had a negative tax differential, implying that the global tax burden on the firm in scope fell. The average tax differential in completed mutual agreement cases is $-4.5 \%$, which is slightly lower than the tax differential in the initial transfer price corrections. The mutual agreement procedural data hence supports the results from the transfer price correction data: that Danish international tax enforcement efforts systematically targets high-tax countries.

Intuitively, firms trying to minimize their global tax bill may fight a transfer price correction whenever this increases the global tax bill and be less resistant whenever it does not. The firm

\footnotetext{
${ }^{12}$ For non-tax havens we use the official statutory corporate tax rates reported by KPMG (2018). For tax havens we use the effective tax rates on profits shifted inwards computed in Tørsløv et. al (2018).

${ }^{13}$ These results do not take into account the fact that some corrections might ultimately be successfully overturned in court, since we do not observe the final court decisions. If we assume an eventual success rate of $70 \%$ uniform across cases, our results imply a decrease in the multinationals' tax bill of $€ 12$ million.
} 
might resist a transfer price correction through a multitude of actions. Firstly, the firm can deliver extensive transfer price documentation in favor of their current pricing, ensuring that the transfer price correction never occurs. We do not have data on this, as we did not get access to the transfer price documentation. 14 Secondly, following a transfer price correction, the firm might fight a transfer price correction by appealing it to the courts. We were able to obtain on list on all initiated court appeals of Danish transfer pricing corrections that were initiated in the period 2011-2016. We were, unfortunately, not able to link this data with the data set on transfer price corrections. Furthermore, we do not know the final outcome of the cases (such as whether the appeal was retracted). In the upper panel of Figure 3, we plot the distribution of tax differentials in the initiated court cases. Interestingly, the distribution of court cases shifts to the right both in comparison to the transfer price correction curve and the full distribution of tax differential between Danish and foreign entities. This suggests that firms have a systematically higher tendency to appeal a transfer price correction whenever this correction increases their global tax bill. From interviews with Danish tax officials we learned that firms often initiate a court case as a safety net while mutual agreement procedures are under way. This is to ensure that they can appeal the correction in court if there is no corresponding correction abroad. In the bottom panel of Figure 3, we try to correct for this behavior by restricting the sample of court cases to those involving EU countries, in which the likelihood of a mutual agreement procedure is high. In this case we see the distribution of tax differential shift further to the right, which supports the notion that firms seem to respond to the tax-differential in their appeal decisions.

To summarize, despite evidence that there is intentional profit shifting to tax havens and little intentional outward profit shifting to high-tax countries, we find that the Danish tax authority corrects few transactions involving tax havens and focuses its resources on correcting transactions involving high-tax countries. As Denmark has a moderate corporate tax rate $(22 \%$ since 2016), this finding implies that the majority of transfer price corrections initiated by Denmark involve countries with higher rates. Because most transfer price corrections initiated by Denmark are followed by successful mutual agreement procedures, these corrections ultimately lower the taxes paid by the targeted multinationals. This result is at odds with the popular perception that the enforcement activities of tax authorities increase the taxes paid by multi-

\footnotetext{
${ }^{14}$ As anecdotal evidence, we interviewed retired tax officials in the European Commission and they supported the notion that firms would provide more extensive documentation for transactions with tax havens. An interesting question for future research would be to study how the extent and quality of transfer price documentation correlates with tax differentials.
} 
nationals. Additionally, we find that firms are systematically more likely to appeal a correction whenever the correction increases the global tax bill of the firm.

\subsection{International Patterns in Transfer Price Corrections}

We complement our analysis of Danish enforcement activities micro-data by analyzing three cross-country aggregate data sources: the EY (2014) transfer price authority survey, Mutual Agreement Procedure statistics from the European Union joint transfer pricing forum and the OECD mutual agreement procedure statistics. These data are less detailed than the Danish data, since they are not at the case-level but aggregated across country; but they cover a large cross-section of countries.

In 2014, the audit firm EY conducted a transfer price authority survey in which they asked 26 major economies which countries were the main focus of their transfer price correction efforts. As shown by the top panel of Figure 4, throughout the world countries most often targeted in transfer price disputes are high-tax countries. The United States comes first, followed by Germany, and Japan. Among tax havens, only Switzerland and the Netherlands show up as being sometimes targeted. Ireland (which according to Tørsløv et al. (2018) is the number one profit shifting destination) is never named among the top-3 targets. Tax authorities also say they look at "low-tax jurisdictions" in the EY survey, but with the exception of Switzerland

and the Netherlands, prominent tax havens are almost never named by tax authorities as being involved in actual disputes. Although tax authorities might intend to go after tax havens, actual transfer price corrections seem to mostly involve non-havens.

Strikingly, if we restrict the EY sample to the countries that have mutual agreement procedures in place, then tax havens feature even more rarely as being targeted, as shown by the bottom panel of Figure 4. The Cayman Islands, Singapore, Hong Kong and the British Virgin Islands are never named among the top 3 targets, and the Netherlands and Switzerland move further down the ranking. This finding is consistent with the notion that mutual agreement procedures that facilitate dispute settlements between high-tax countries may crowd out enforcement on tax havens, which we discuss in section 6.1.

Figure 5 shows the distribution of active mutual agreement procedures under the Arbitrage Convention in the European Union in 2011, the most recent year for which bilateral information is available. These are cases where (i) a transfer price correction has been conducted by a EU country, (ii) the targeted firm has asked the tax authority to initiate a mutual agreement procedure to lower the tax base in the partner country, and (iii) the Arbitration Convention 
has been invoked, giving the tax authorities involved a 2-year deadline before an external panel is brought in. Strikingly, we see that only $10.7 \%$ of mutual agreement procedures initiated by high-tax EU countries involve an EU tax haven 15 , while close to $90 \%$ involve EU high-tax countries. One caveat to keep in mind here is that a company may not bother to request a mutual agreement procedure if profits are being relocated away from a tax haven where the firm's effective tax rate is close to zero. The EY and Danish data do not suffer from this limitation, since they do not condition on the existence of a mutual agreement procedure.

In an effort to curb profit shifting the OECD has started the "Inclusive framework on Base Erosion and Profit Shifting". This framework consists of 137 member countries (including all major tax havens) that all committed to publish statistics on the number of mutual agreement procedures opened, closed, and the inventory of ongoing cases ${ }^{16}$ In Figure 6 , we plot the the number of mutual agreement cases closed in 2018 by the target country (the country set to give up tax base). Strikingly, only $8 \%$ of all mutual agreement procedures closed targeted tax havens. Again, the number of cases against Ireland is remarkably low, just 8 cases closed in 2018. Similarly, Singapore, the World's second largest tax haven according to Tørsløv et al. (2020) only closed 11 cases. Again there is the caveat that a company may not bother to request a mutual agreement procedure if profits are being relocated away from a tax haven where the firm is not paying any taxes. This may aid to explain why no mutual agreement procedures where closed in prominent tax havens such as the Cayman Islands, Jersey and Isle of Man. Nonetheless, the Danish data, EY data and mutual agreement procedure data all tell a very similar story: the focus of international tax enforcement does not seem to be tax havens but instead high-tax countries.

\section{Explaining the Patterns in International Tax Enforce- ment: Benchmark Model}

Why, if there is intentional (and by some estimates large) profit shifting to tax havens, do tax authorities in high-tax countries focus on correcting non-intentional mistakes in transactions involving high-tax countries? This section presents a model that can explain this puzzle.

In our model, a tax authority in a high-tax country seeks to maximize the amount of revenue collected from transfer price corrections. The tax authority faces a constraint on the total amount of corrections that it can undertake in a given year. We assume there are two

\footnotetext{
${ }^{15}$ As defined by Tørsløv et al. (2018): Belgium, Cyprus, Ireland, Malta, Netherlands and Luxembourg

${ }^{16}$ The statistics follow agreed reporting framework and are made publicly available on the OECD webpage
} 
representative firms: a non-tax planning firm and a tax planning firm

The non-tax planning firm conducts intra-group transactions between subsidiaries located in high-tax countries with identical tax rates. It has thus no incentive to shift profits between subsidiaries. However, when setting its transfer prices the non-tax planning firm makes nonintentional mistakes leading to transfer prices deviating from the arm's-length price on certain transactions. These mistakes are not systematic: if these mistakes were left uncorrected, the non-tax planning firm's aggregate income in each country would not deviate from the situation where all transactions were priced according to the arm's-length principle. Nonetheless, the tax authority of each high-tax country has an incentive to correct these mistakes, because these corrections increase the tax base in the correcting country (at the expense of the partner country). Corrections may fail with some likelihood if the firm challenges the correction in court or during the mutual agreement procedures. A successful transfer price correction of a transaction between the two high-tax countries will not affect the global tax payments of the firm.

The tax planning firm seeks to shift as much income as possible from high-tax countries to low-tax countries. The firm does this by mispricing an internal service transaction between the high-tax country and the low-tax country. The optimal behavior of the tax planning firm is to always choose a transfer price that maximizes the amount of profit book in the tax haven but does not get corrected. That is, the tax-planning firm will shift profits to the tax haven up to the point where for the high-tax country's tax authority, the marginal yield of correcting the non-tax planning firm and the tax planning firm is the same. As mutual agreement procedures facilitate correcting the non-tax planning firm, such procedures increase the yield of correcting the non-tax planning firm. When the yield of correcting the non-tax planning firm increases this in turn allows the tax-planning firm to shift more income to the low-tax country without being corrected. As a result, mutual agreement procedures can increase intentional profit shifting to tax havens, by shifting the resources of the tax authority from intentional profit shifting to unintentional mistakes. Similarly, we find that country-by-country minimum taxation can lower the incentive for tax authorities to pursue profits reported in tax havens and hence increase intentional profit shifting.

We extend the model to allow high-tax authorities to invest in obtaining revenue from other high-tax countries through transfer price corrections. We find that high-tax countries will enter into an arm's race and invest in relocating tax bases from each other despite this having no effect on global tax revenue-hence leading to a socially sub-optimal equilibrium. 
Additionally, similar to the findings of Becker and Davies (2014), we find that the taxplanning firm will incur large legal costs to fight the tax authority in the high-tax county and hence disincentivize the authority to correct its transactions with the low-tax country.

\subsection{Setup of the Model}

We begin with the simplest setup: A tax authority in a high-tax country deciding whether to correct transactions with another high-tax country or to correct a transaction with a low-tax country.

\section{The model consists of three agents:}

1. A non-tax planning firm consisting of 2 entities: one in high-tax country $\mathrm{H} 1$ and the other in high-tax country $\mathrm{H} 2$.

2. A tax authority operating in high-tax country H1.

3. A tax planning firm consisting of 2 entities: one in high-tax country $\mathrm{H} 1$ and the other in low-tax country L.

\section{The choice variables of the agents are:}

1. The tax planning firm decides how to set the transfer price $p^{L}$ on its internal transaction between the high-tax country $\mathrm{H} 1$ and the low-tax country L.

2. Country H1 decides which transfer prices to correct.

\section{The exogenous variables of the model are:}

1. $p^{a}$, the arm's length price (constant for simplicity)

2. $N$, the continuum of services imported by the non-tax planning firm in country $\mathrm{H} 1$ from its affiliate in country $\mathrm{H} 2$.

3. $t_{H 1}, t_{H 2}$, and $t_{L}$, the corporate tax rates in countries $\mathrm{H} 1, \mathrm{H} 2$ and $\mathrm{L}$, respectively. We assume that $t_{H 1}=t_{H 2}>>t_{L}$.

4. $\epsilon_{i}=p_{i}^{H}-p^{a}$, the accidental transfer price deviation on transactions between the two high-tax countries. We assume these mistakes are unknown and unintentionally made by the non-tax planning firm, but known by the tax authority. Further, we assume these mistakes follow a uniform distribution with standard deviation $b$ and mean zero. 
5. $\bar{N}$, the resource constraint facing the tax authority in country H1.

\section{Variables that are exogenous in the basic model, but later made endogenous:}

1. $\gamma_{H}$, the ease of doing transfer price corrections between the two high-tax countries H1 and $\mathrm{H} 2$.

2. $\gamma_{L}$, the ease of country $\mathrm{H} 1$ doing a transfer price correction involving the low-tax country L.

\subsection{The Non-Tax Planning Firm}

The non-tax planning firm has an affiliate in country $\mathrm{H} 1$ which is importing a continuum of services indexed by $i$ from its affiliate in country $\mathrm{H} 2$ at the price $p_{i}^{H}$; by definition $\int_{0}^{N} i d i=N$. An increase in any of the transfer prices applied will increase the taxable income of the firm in country $\mathrm{H} 2$ and lower the taxable income in country $\mathrm{H} 1$ by the same amount, leaving the global income of the firm unchanged. For simplicity, we further assume that $t_{H 1}=t_{H 2}$, such that the global tax bill of the firm is also unaffected by the transfer price. That is, an increase in $p_{i}^{H}$ by 1 will lower tax receipts in country $\mathrm{H} 1$ by $t_{H 1}$ but increase the tax receipts in country $\mathrm{H} 2$ by $t_{H 2}=t_{H 1}$ and hence leave global tax receipts unchanged.

Lemma 1: As $t_{H 2}=t_{H 1}$, a transfer price correction of transactions between the two hightax countries does not effect global tax receipts.

According to prevailing tax rules, the non-tax planning firm should price its intra-group transactions at the arm's-length price $p^{a}$, which is for simplicity assumed to be constant across services. However, due to the lack of tax consequences of the transfer price chosen, the firm is inattentive and does not always apply the arm's-length principle 17 This leads the non-tax planning firm to accidentally mis-price its transactions by $\epsilon_{i}=p_{i}^{H}-p^{a}$. We assume that these mistakes are uniformly distributed around the correct transfer price such that $\epsilon_{i} \sim U(-b, b)$ and $\int_{0}^{N} \epsilon_{i} d i=0$. If all transactions between the two high-tax countries where priced correctly the total value of internal imports would be $\int_{0}^{N} p^{a} d i=p^{a}$. If the non-tax planning firm was

\footnotetext{
${ }^{17}$ This assumption can be justified by assuming a fixed cost of knowing the actual arm's-length price $p^{a}$ or an increased focus on non-tax considerations. Non-tax considerations relates to efficiency transfer pricing (as generally taught in Management Accounting) — that is, ensuring transfer pricing reflects the needs and opportunity costs of the firm - e.g. an optimal transfer price on head quarter services might be zero if a firm has idle resources in the head quarter. See Nielsen and Raimondos-Moller (2008) for a fuller discussion of the trade-off between tax and non-tax motivated transfer pricing.
} 
never corrected the total value of internal imports would be $\int_{0}^{N} p^{a}-\epsilon_{i} d i=p^{a}$. This implies that while individual transactions between the two high-tax countries may be mis-priced there is no aggregate deviation from the arm's-length principle.

Lemma 2: If the transfer prices of the non-tax planning firm are not corrected by the tax authorities, there will be no aggregate deviation from the arm's-length principle as arm'slength price deviations on individual transactions between the two high-tax countries are nonsystematic.

\subsection{The Tax Authority in Country H1}

We first consider the behavior of the tax authority in country $\mathrm{H} 1$ and assume that it seeks to maximize the tax revenue collected from transfer price corrections. We additionally assume that the tax authority has a limited amount of resources, which implies that following through with one transfer price correction lowers the amount of resources available to pursue another case. We model this constraint simply by assuming that the tax authority can do a maximum of $\bar{N}$ corrections per year, where $0<\bar{N}<1$.

Corrections may ultimately be invalidated or reduced in the context of a mutual agreement procedures and/or in court. We allow the expected decrease in the initial correction to depend on the partner country. We let $\left(1-\gamma_{H}\right)$ denote the expected decrease in a correction of the non-tax planning firm and $\left(1-\gamma_{L}\right)$ denote the expected decrease in a correction of the tax planning firm. A plausible hypothesis is that the tax-planning firm will resist corrections that move taxable income from the low-tax country to the high-tax country (as these corrections increase its global tax payments), implying that $\gamma_{L}<\gamma_{H}$. This assumption, however, is not necessary to show Proposition 1 below.

\subsection{Correcting Mistakes Only}

We begin by disregarding the tax-planning firm and describe a situation where the tax authority only corrects the mistakes of the non-tax planning firm. The expected yield to the tax authority of correcting service transaction $i$ of the non-tax planning firm is $t_{H 1} \gamma_{H} \epsilon_{i}$. For any $z \in[-b, b]$ we denote the number of service transactions for which $\epsilon_{i}>z$ as $F(z)$ and following the properties of the uniform distribution we note that: 


$$
F(z)=\frac{b-z}{2 b}
$$

The tax authority will correct the $\bar{N}$ largest mistakes $\left(\epsilon_{i}\right)$ of the non-tax planning firm conditional on $\epsilon_{i}>0$ in all $\bar{N}$ cases. We let $\epsilon^{N}$ denote the the $\bar{N}^{\prime}$ th largest mistake and note that:

$$
F\left(\epsilon^{N}\right)=\frac{b-\epsilon^{N}}{2 b}=\bar{N}=>\epsilon^{N}=b-2 b \bar{N}
$$

This implies that the correction of the $\bar{N}$ 'th largest mistake of the non-tax planning firm will generate a yield of $Y^{N}=t_{H 1} \gamma_{H}(b-2 b \bar{N})$. If $Y^{N}<0$ the tax authority will not correct all $\bar{N}$ corrections (as doing so would reduce the taxable income of country H1) but only correct the number of transactions for which $Y^{N}>0$. From equation 2 it follows that:

$$
t_{H 1} \gamma_{H}(b-2 b \bar{N})>0=>\bar{N}>\frac{1}{2}
$$

The tax authority will hence correct $\bar{N}$ transactions unless $\bar{N}>\frac{1}{2}$ in which case the tax authority will only correct $\frac{1}{2}$ transactions. At the optimum the expected marginal yield $\left(Y^{*}\right)$ of correcting the non-tax planning firm alone is:

$$
Y^{*}= \begin{cases}t_{H 1} \gamma_{H}(b-2 b \bar{N}) & \text { if } \bar{N}<\frac{1}{2} \\ 0 & \text { if } \bar{N} \geq \frac{1}{2}\end{cases}
$$

\subsection{Intentional Profit Shifting in Equilibrium}

The tax-planning firm imports one service from its affiliate in the low-tax country L at transfer price $p^{L}$. The goal of the tax planning firm is to maximize $p^{L}$ such that it transfers as much income as possible from the high tax country to the low tax country. The expected yield to the tax authority of correcting the tax planning firm is $t_{H 1} \gamma_{L}\left(p^{L}-p^{a}\right)$. The tax-planning firm knows the expected marginal yield of correcting the non-tax planning firm $\left(Y^{*}\right)$ and will hence ensure that the tax authority does not correct $p^{L}$ by making it more attractive to correct the marginal transaction of the non-tax planning firm. The optimal transfer price $p_{*}^{L}$ thus satisfies:

$$
\begin{gathered}
Y^{*}=t_{H 1} \gamma_{L}\left(p_{*}^{L}-p^{a}\right) \\
p_{*}^{L}-p^{a}= \begin{cases}\frac{\gamma_{H}}{\gamma_{L}}(b-2 b \bar{N}) & \text { if } \bar{N}<\frac{1}{2} \\
0 & \text { if } \bar{N} \geq \frac{1}{2}\end{cases}
\end{gathered}
$$


If the tax authority has sufficient capacity $\bar{N}>\frac{1}{2}$ the tax authority can pursue all cases that increase the taxable income of country $\mathrm{H} 1$ and there is hence no need for the tax authority in country $\mathrm{H} 1$ to prioritize between cases (they just pursue them all). In such a case the tax planning firm will not be able to shift any profits to the low-tax country. In practice, we know that the tax authority have to do some prioritization and cannot pursue all cases so we focus on the situation where the tax authority is sufficiently constrained, i.e., $\bar{N}<\frac{1}{2} \cdot \sqrt{18}$ In this case we have the following Proposition:

Proposition 1: If the tax authority is sufficiently constrained ( $\left.\bar{N}<\frac{1}{2}\right)$, the amount of intentionally shifted profits to the low-tax country $\left(p_{*}^{L}-p^{a}\right)$ depends positively on $b$ (the size of the mistakes made by the non-tax planning firm), negatively on $\gamma_{L}$ (the ability to correct the tax-planning firm) and positively on $\gamma_{H}$ (the ability to correct the mistakes of the non-tax planning firm).

Proposition 1 shows how corrections of of non-intentional profit shifting crowds out corrections of intentional profit shifting by the tax-planning firm. The larger the mistakes of the non-tax planning firm $(b)$ and the larger the success rate of correcting these mistakes $\left(\gamma_{H} / \gamma_{L}\right)$, less resources will be devoted to correct intentional profit shifting and, as a result, the higher the transfer price deviation $p_{*}^{L}-p^{a}$ will be.

\subsection{Global Maximum Tax Collection vs Equilibrium}

What would be the optimal allocation of resources if the tax authority aimed to maximize global tax collections? As the two high-tax countries have identical tax rates, a transfer price correction between these two countries does not impact global tax collections (lemma 1) Furthermore, If the tax authority is sufficiently constrained $\left(\bar{N}<\frac{1}{2}\right)$, corrections of intentional profit shifting to the low-tax country will be crowded out by corrections between the two high-tax countries in equilibrium (proposition 1). From lemma 1 and proposition 1 it hence follows that corrections of transactions between the two high-tax countries (which in isolation have a neutral impact on global tax collections) lowers global tax collections by replacing corrections of intentiona profit shifting (that generate a global tax surplus).

Proposition 2: If the tax authority is sufficiently constrained $\left(\bar{N}<\frac{1}{2}\right)$, corrections of in-

\footnotetext{
${ }^{18}$ In reality tax authorities only have capacity to audit a tiny fraction of transactions.
} 
tentional profit shifting to the low-tax country will be crowded out by corrections between the two high-tax countries in equilibrium. As a result, tax collections fall below the global maximum

Proposition 2 is the result of the tax authority failing to take into account the tax externality that occurs in the correction of transfer prices. That is, the tax authority fails to take into account the reduction in foreign tax collection that occurs whenever it corrects transfer prices. By failing to internalize this tax externality the tax authority chooses to conduct transfer price corrections that have zero impact on the multinational firms global tax bill instead of prioritizing intentional profit shifting. This situation is pareto-inferior as all countries could be made better of by the tax authority only correcting the intentional profit shifting and sharing the additional tax receipts.

\section{Extensions of the Model}

\subsection{Potential Adverse Effects of Improving Mutual Agreement Pro- cedures}

Mutual agreement procedures (MAP) facilitates an agreement between tax authorities, such that the a transfer price correction in one country is met by an equal reduction in the tax base of the counterpart country. This matters a lot when the counterpart country has a high tax rate and matters less if the the counterpart country has a low tax rate. In the extreme case where the counterpart country has a zero tax rate there is no point of initiating dispute resolution, as there is no tax consequence of lowering the tax base in a country with a zero tax rate. Hence, by construction, improvements in the mutual agreement procedure incentivizes corrections of transactions between high-tax countries more than it incentivizes corrections involving a lowtax country. This is consistent with the empirical findings from section 3.2 , that the recent mutual agreement procedure drive led to a marked increase in procedures targeting high-tax countries but only a marginal increase in procedures targeting tax havens. We can simplistically model the impact of the mutual agreement procedures as an increase in the relative yield from correcting transactions between high-tax countries compared to transactions with the low-tax country, i.e. an increase in $\frac{\gamma_{H}}{\gamma_{L}}$. It then follows that:

Corollary 1.1: Potential adverse effects of improving mutual agreement procedures. If we

interpret an improvement of the mutual agreement procedures as an increase in $\frac{\gamma_{H}}{\gamma_{L}}$ it follows from proposition 1 that improving mutual agreement procedures will increase the amount of 
profits shifted to the low-tax country - insofar as the tax authority is sufficiently capacity constrained $\left(\bar{N}<\frac{1}{2}\right)$.

By increasing the yield of correcting transactions with high-tax countries, mutual agreement procedures increase the opportunity cost of correcting transactions with low-tax countries. The shift of resources by the tax authority allows the tax-planning firm to shift more income to tax havens. This implies that recent policies aimed at strengthening mutual agreement procedures may have increased the scope for intentional and tax-motivated profit shifting and that the current push for mandatory dispute settlement may further increase tax-motivated profit shifting.

\subsection{Potential Adverse Effects of Country-By-Country Minimum Tax- ation}

A large number of countries have implemented country-by-country minimum taxation through controlled foreign corporation (CFC) rules such as the US GILTI regime.19 The OECD secretariat is currently pushing a global roll-out of such policy through the Global Anti-Profit Shifting proposal (OECD 2019b). Under country-by-country minimum taxation a foreign subsidiary facing tax rate below a set minimum tax rate $t<t_{\min }$ will be taxed on the residual difference $t-t_{\min }$ in the home country.

To understand the potential impact on the incentives facing the tax authority we now introduce country-by-country minimum taxation in country H1. To begin with we assume that the the minimum tax rate is above the tax rate in the low-tax country $\left(t_{L}<t_{\text {min }}\right)$ but below the rate in the high-tax country $\mathrm{H} 2\left(t_{H}>t_{\text {min }}\right)$ and that both multinationals have their parent in country H1. These assumptions characterizes the current country-by-country minimum tax rules already implemented and the OECD (2019b) proposal (see section 7). In this case profits reported by the tax-planning firm will already be subject to some taxation in country H1 (taxed at $t_{\text {min }}-t_{L}$ ) while none of the reported profits in country $\mathrm{H} 2$ are subject to taxation in country H1. If the tax authority in country H1 was to correct a transfer price deviation the expected value under country-by-country minimum taxation now falls to $\left(t_{H 1}-t_{\min }\right) \gamma_{L}\left(p^{L}-p^{a}\right)$, which is a fraction $1-t_{\min }$ of the expected value without minimum taxation. Country-by-country minimum taxation in this case lowers the expected value to the tax authority of correcting the tax planning firm. In turn this allows the tax planning firm to shift more profits to the

\footnotetext{
${ }^{19} \mathrm{https}$ //www.irs.gov/newsroom/irs-and-treasury-issue-guidance-related-to-global-intangible-low-taxedincome-gilti
} 
low-tax country, as the tax authority will be less prone to correcting these transactions. The new equilibrium level of intentional profit shifting becomes

$$
p_{*}^{L}-p^{a}= \begin{cases}\frac{\gamma_{H}}{\gamma_{L} \cdot\left(1-t_{\text {min }}\right)}(b-2 b \bar{N}) & \text { if } \bar{N}<\frac{1}{2} \\ 0 & \text { if } \bar{N} \geq \frac{1}{2}\end{cases}
$$

Intentional profit shifting to the low-tax country hence increases by a factor of $1-t_{\min }$ if the tax authority is sufficiently constrained. Of course this result changes dramatically if the minimum tax is set equal to the tax rate in country H1 (world wide taxation), such that $t_{\text {min }}=t_{H 1}=t_{H 2}$ in which case the tax planning firm has no incentive to shift profits (as they will be taxed at the same rate everywhere).

Proposition 3: The existence of country-by-country minimum taxation, which is binding for the low-tax country and non-binding in the high-tax country, will increase intentional profit shifting in equilibrium - insofar as the tax authority is sufficiently capacity constrained $(\bar{N}<1 / 2)$

In the following we will, for the sake of simplicity, ignore the existence of country-by-country minimum taxation.

\subsection{Tactical Use of Transfer Price Documentation and Legal Pres- sure}

So far the tax-planning firm has only chosen the tax-minimizing transfer price $p_{*}^{L}$ (and the nontax-planning firm has not chosen anything). We now introduce the option of investing in higherquality transfer price documentation, applying legal pressure (e.g., through court procedures) and creating a veil of opacity (e.g., through limited liability companies). The simplest way to model this is by making $\gamma_{i}$ endogenous such that firms can lower the chance of a successful transfer price corrections by incurring legal costs $C$. We assume that:

$$
\frac{\delta \gamma_{i}}{\delta C}<0, \frac{\delta^{2} \gamma_{i}}{\delta^{2} C}>0
$$

As there is no benefit to the non-tax planning firm of lowering the likelihood of a transfer price corrections, the non-tax-planning firm will not incur any legal costs $(C=0)$. By contrast, following proposition 1 the tax-planning firm can increase its tax benefit from transfer mispricing by lowering the likelihood of a transfer price correction as long as the tax authority is 
sufficiently resource constrained. The maximization problem for the tax-planning firm in this case becomes (here using eq. 7):

$$
\operatorname{Max}_{w r t C}\left[\left(t_{H}-t_{L}\right) \cdot\left(p_{*}^{L}-p^{a}\right)\right]= \begin{cases}\operatorname{Max}_{w r t} C\left[\frac{\left(t_{H}-t_{L}\right) \gamma_{H}}{\gamma_{L}}(b-2 b \bar{N})-C\right] & \text { if } \bar{N}<\frac{1}{2} \\ \operatorname{Max}_{\text {wrt } C}[(0-C] & \text { if } \bar{N} \geq \frac{1}{2}\end{cases}
$$

From eq. 9 and 8 it follows that if the tax authority is sufficiently constrained $\left(\bar{N}<\frac{1}{2}\right)$ the tax-planning firm will incur legal costs up to the point in which the marginal benefit of distracting the tax authority equals the marginal cost $-\left(t_{H}-t_{L}\right) \gamma_{H}(b-2 b \bar{N})=\frac{\delta C}{\delta \gamma_{L}}=>C>0$. That is, insofar the tax authority is sufficiently resource constrained, the tax-planning firm will invest in making it difficult to correct its intentional profit shifting. This implies that, all other things equal, it will be more costly to the tax authority to correct the tax-planning firms intentional profit shifting than correcting unintentional mistakes by the non-tax planning firm. As a result, the tax authority will be less likely to target the tax-planing firm in transfer pricing corrections and profit shifting increases (following proposition 1).

Proposition 4: In equilibrium the tax planning firm will incur legal costs $C>0$ to dissuade the tax authority to correct its intentional profit shifting - insofar the tax authority is sufficiently constrained $(\bar{N}<1 / 2)$. This increases profit shifting in equilibrium.

\subsection{High-Tax Countries Arms Race}

We now introduce the tax authority of high-tax country $\mathrm{H} 2$ with an analogue objective of country H1. We allow the tax authorities to have differing capacity and let $\bar{N}_{H 1}, \bar{N}_{H 2}$ denote the constraint in country $\mathrm{H} 1$ and $\mathrm{H} 2$, respectively. We continue to assume that the tax authorities are constrained to the point where $\bar{N}_{H 1}, \bar{N}_{H 2}<\frac{1}{2}$. Without loss of generality simplicity we assume that the only multinational operating in country $\mathrm{H} 2$ is the non-tax planning firm. While the tax authority in country $\mathrm{H} 1$ wants to correct the mistakes of the non-tax planning firm whenever the transfer price is too high $\left(\epsilon_{i}=p_{i}^{H}-p^{a}>0\right)$ the tax authority in country $\mathrm{H} 2$ faces the opposite incentive (as the host of the exporting affiliate). Its tax base increases with $p_{i}^{H}$ and hence it will aim to correct transfer prices that are too low $\left(p_{i}^{H}-p^{a}<0\right)$. We allow the enforcement capacities (proxied by $\gamma_{H}$ ) of the 2 tax authority to differ. We let $\gamma_{H}^{H 1}$ denote the success rate of the tax authority in country $\mathrm{H} 1$ and $\gamma_{H}^{H^{2}}$ denote the success rate of the tax authority in country $\mathrm{H} 2$. 
Remembering that the number of services for which $\epsilon_{i}>z$ is given by eq. 11, it follows that the total value of the $\bar{N}_{H 1}$ largest corrections of the non-tax planning firm in country H1 is:

$$
t_{H 1} \gamma_{H}^{H 1} \int_{0}^{\bar{N}_{H 1}} b-2 b x d x=t_{H 1} \gamma_{H}^{H 1}\left[b x-b x^{2}\right]_{0}^{\bar{N}_{H 1}}=t_{H 1} \gamma_{H}^{H 1}\left(b \bar{N}_{H 2}-2 b \bar{N}_{H 1}^{2}\right)
$$

Similarly, the value of the $\bar{N}_{H 2}$ largest corrections of the non-tax planning firm in country $\mathrm{H} 2$ is:

$$
-t_{H 2} \gamma_{H}^{H 2} \int_{0}^{\bar{N}_{H 2}}-(b-2 b x) d x=t_{H 2} \gamma_{H}^{H 2}\left[b x-b x^{2}\right]_{0}^{\bar{N}_{H 2}}=t_{H 2} \gamma_{H}^{H 2}\left(b \bar{N}_{H 2}-2 b \bar{N}_{H 2}^{2}\right)
$$

The total direct impact of all transfer price corrections on the tax base of each country is the sum of each country's own corrections less the corrections of the partner country. Additionally, as we have assumed that $t_{H 1}=t_{H 2}$ the direct net impact on global tax revenue of any transfer price correction between the two high-tax countries is always zero. Finally, following corollary 1.1, global tax collection fall whenever the tax authority in country H1 corrects transactions with country $\mathrm{H} 2$, as these corrections crowds out the enforcement of the tax-planning firm.

We now allow the success rate of each tax authority to be the result of an investment in tax capacity of $I$ (human capital, technology, etc.):

$$
\begin{array}{ll}
\frac{\delta \gamma_{H}^{H 1}}{\delta I^{H 1}}>0, & \frac{\delta^{2} \gamma_{H}^{H 1}}{\delta^{2} I^{H 1}}<0 \\
\frac{\delta \gamma_{H}^{H 2}}{d I^{H 2}}>0, & \frac{\delta^{2} \gamma_{H}^{H 2}}{d^{2} I^{H 2}}<0
\end{array}
$$

Where $I_{H 1}$ is the investment made by country $\mathrm{H} 1$ and $I_{H 2}$ is the investment made by country H2. From a social point of view any investment in conducting transfer price corrections between the two high-tax countries is sub-optimal. In the case of country H2 correcting country H1, these corrections have no impact on global tax payments and there carry a social cost but no social value. In the case of country $\mathrm{H} 1$ correcting country $\mathrm{H} 2$, these corrections in fact lower global tax payments by crowding out enforcement of transactions to the low-tax country - hence allowing the tax-planning firm to push the envelope further and shift more profits. However, each tax authority simply tries to maximize the sum of corrections and in a Nash-equilibrium both tax authorities will therefore invest in $\gamma_{H}$ up to the point where the marginal (private) return equals the marginal cost.

$$
\frac{\delta \gamma_{H}^{H 1}}{\delta I_{*}^{H 1}}=t_{H 1}\left[b \bar{N}_{H 1}-2 b \bar{N}_{H 1}^{2}\right]
$$




$$
\frac{\delta \gamma_{H}^{H 2}}{\delta I_{*}^{H 1}}=t_{H 2}\left[b \bar{N}_{H 2}-2 b \bar{N}_{H 2}^{2}\right]
$$

Several interesting conclusions are visible from eq. 14 and 15. First, both high-tax countries will invest a positive amount in obtaining revenue from each other by correcting mistakes in a Nash-equilibrium - leading to a sub-optimal outcome from a global perspective. Second, all other things equal, the tax authority with the highest capacity $\bar{N}_{H 2}$ will invest more in obtaining relocating the base from the other high-tax country and as a result obtain a higher share of total tax revenue. This second point has important implications when considering the dynamic of transfer price corrections between high- and low-income countries. Concretely, one might fear that resource-constrained tax-authorities in developing countries cannot match the efforts of high-income countries and as a result lose in this (non-tax driven) game for profits.

Proposition 4: In a Nash-equilibrium, both high-tax countries will invest in relocating some tax base from away from the other country, despite this having no effect on global tax revenuehence leading to a socially sub-optimal equilibrium. All other things equal, the tax authority with the highest tax capacity will end up obtaining the most tax revenue.

\subsection{An Alternative Explanation: Tax Authority Lowering Effective Taxation To Attract Domestic Investment}

Another explanation for the observed patterns in transfer price enforcement (i.e., the lack of enforcement against tax havens) is that tax authorities may not really be interested in enforcing taxes on multinationals. With territorial tax systems, lax enforcement can encourage domestic investment by lowering effective marginal tax rates on multinationals. The tax authorities of high-tax countries might perceive that profit shifting and capital mobility are strongly substitutable — with less shifting there would be more outflows of tangible capital, with potentially adverse effects on wages and employment - and rationally chose to limit enforcement for that reason (see e.g Hong and Smart (2010) for a formalization of the argument that individual governments might welcome tax havens). From the viewpoint of the individual tax authority you can increase the tax revenue (in your country) while keeping constant (or even lowering) the excess burden of taxation. Following, for example, the theoretical framework for optimal tax administration of Keen and Slemrod (2017) the tax authority should prioritize cases that would lower the tax burden of the firm-i.e., the tax authority should, ceteris paribus, chose cases involving high-tax countries as the corresponding party. 


\section{Conclusion}

This paper investigates the enforcement of taxes on multinational companies. Empirically, the available evidence suggests that tax authorities in high-tax countries seem to spend the bulk of their resources correcting non-intentional deviations from arm's length pricing occurring in transactions between high tax countries, while spending a relatively small fraction of their resources correcting transactions involving tax havens. We show how this behavior can be explained by the incentives that tax authorities face. Tax authorities do not internalize the externality of their transfer price corrections on foreign nations. We further show how this current incentive structure can lead to a socially sub-optimal arms race, where high-tax countries spend resources on stealing a bit of revenue from each other with little impact on the global tax bill of multinationals. Meanwhile, tax-planning firms reap the benefits of distracted tax authorities by shifting more profits to tax havens.

Our results suggest that current policy efforts aimed at encouraging international dispute resolution settlements might exacerbate profit shifting to tax havens. The OECD has launched an initiative to curb base erosion and profit shifting (BEPS). Action 14 of this plan calls for more effective dispute resolution mechanisms (OECD, 2015). 135 member countries of the inclusive framework have committed to implement a minimum standard to strengthen the effectiveness and efficiency of mutual agreement procedures 20 Moreover, the current OECD secretariat BEPS 2.0 proposal suggests introducing mandatory dispute settlement mechanisms: 'it would be essential to consider existing and possible new approaches to dispute prevention and resolution, including mandatory and effective dispute prevention and resolution mechanisms to ensure the elimination of protracted disputes and double taxation' (OECD 2019, pp.16). What this exactly entails is unclear, but the EU's Arbitrage Convention, where an external panel may ultimately decide the appropriate transfer price, may be the model OECD wish to copy. The European Union does not only promote dispute resolution through the Arbitrage Convention, but additionally through the joint transfer pricing where the ease of disputes is continuously improved ${ }^{21}$ But the easier it is for, say, the French tax authority to relocate profits booked in Germany, the less resources France may devote to chasing the profits shifted to Bermuda-potentially increasing shifting to low-tax locales. The efforts at the OECD and the EU in promoting dispute resolution may as a result have the adverse effect of incentivizing corrections between high-tax

\footnotetext{
${ }^{20}$ https://www.oecd.org/tax/beps/beps-actions/action14/

${ }^{21}$ https://ec.europa.eu/taxation_customs/business/company-tax/transfer-pricing-eu-context/ joint-transfer-pricing-forum_en
} 
countries and as a result may crowd out corrections of intentional profit shifting.

We also highlight the potential adverse effects of country-by-country minimum taxation currently being pushed by the OECD secretariat in the Global Anti-Base Erosion proposal OECD (2019b) and already implemented in a wide range of countries ${ }^{22}$. The issue is that the country-by-country minimum rate already implemented in some countries are commonly substantially below the high-tax country average tax rate as is the case for the minimum tax discussed in the OECD ${ }^{23}$ This implies that under country-by-country minimum taxation, tax authorities will find that the benefit of correcting transfer prices are lower in cases involving tax havens. Say that a host country with a tax rate of $25 \%$ has a minimum tax rate of foreign entities of $12 \%$ and that a tax-planning firm has shifted their income to Ireland paying an effective tax rate of $0 \%$. In this case, bringing $€ 1$ of profits back to the home country from Ireland will only create a net revenue increase corresponding to the tax rate differential $25 \%$ $12 \%$ - whereas the reward of bringing $€ 1$ from a high-tax country will be the full $25 \%$. Hence low country-by-country minimum taxes may suffer from the fallacy of redirecting the attention of tax authorities away from intentional profit shifting towards unintentional mistakes. The impact of introducing a high minimum tax (at the level of the home economy) are very different as they could eliminate the incentive to shift profits.

As with other issues in international taxation, a coordinated effort (such as a federal transfer pricing unit at the EU level) could go along way towards fixing the problem. Another potential solution involves abandoning the transfer pricing principle. A number of proposals for fundamental reforms that would make profit shifting harder have recently been formulated, for instance the adoption of a destination-based corporate cash flow tax (Auerbach, 2010) or the use of a formulary apportionment system (e.g., Avi-Yonah and Clausing, 2007). Alternatively, a combination of reforms could be imposed; such as source taxation (world-wide taxation) for domiciled firms combined with formula apportionment for foreign subsidiaries (see Saez and Zucman 2019 for a discussion of this). This paper suggests that these reforms might save public and corporate resources by freeing resources currently used for wasteful tax enforcement.

\footnotetext{
${ }^{22}$ Most recently the US GILTI rules resembles minimum taxation rules. See https://taxfoundation.org/ cfc-rules-around-the-world for an overview

${ }^{23}$ The global average corporate tax rate in 2019 was $24 \%$ (KPMG Corporate Tax Tables) but the OECD 2019b discusses examples of a $15 \%$ minimum tax rate. US GILTI implies a minimum tax rate of less than $13 \%$ on some types of profits and lower still for others. UK, Spanish and South African CFC rules kicks in at $75 \%$ of the home country tax rates - Chinese and French CFC rules kicks in at $50 \%$ of the home country rate
} 


\section{References}

Auerbach, Alan J. 2010. "A Modern Corporate Tax." The Hamilton Project/Center for American Progress, December.

Alvarez-Martinez, M., Barrios, S., d'Andria, D., Gesualdo, M., Nicodème, G. and Pycroft, J. 2018. "How Large is the Corporate Tax Base Erosion and Profit Shifting? A General Equilibrium Approach".

Avi-Yonah, Reuven S., and Kimberly A. Clausing. 2007. "Reforming Corporate Taxation in a Global Economy: A Proposal to Adopt Formulary Apportionment", Hamilton Paper Discussion project 2007-08.

Becker, Johannes and Ronald B. Davies. 2014. "A Negotiation-Based Model of TaxInduced Transfer Pricing". CESifo working paper \#4892.

Becker, J., Davies, R.B. and Jakobs, G. 2017. "The economics of advance pricing agreements". Journal of Economic Behavior \& Organization, 134, pp.255-268.

Becker, J., Johannesen, N. and Riedel, N. 2018. "Taxation and the allocation of risk inside the multinational firm".

Bernard, Andrew B., J. Bradford Jensen, and Peter K. Schott. 2006. "Transfer Pricing by U.S. Based Multinational Firms". NBER working paper \#12493.

Clausing, Kimberly A. 2003. "Tax-motivated transfer pricing and US intrafirm trade prices". Journal of Public Economics, 87: 2207-2223.

Clausing, Kimberly A. 2016. "The Effect of Profit Shifting on the Corporate Tax Base in the United States and Beyond." National Tax Journal, 69(4), 905-934.

Cristea, Anca D. and Daniel X. Nguyen. 2016. "Transfer Pricing by Multinational Firms: New Evidence from Foreign Firm Ownerships." American Economic Journal: Economic Policy, 8(3): 170-202.

DSA - Danish State Auditors (Rigsrevisionen). 2014. "Beretning til Statsrevisorerne om SKATs indsats påtransfer pricingområdet". available online at http://www.rigsrevisioner. $\mathrm{dk} /$

Davies, R. B., Martin, J., Parenti, M., and Toubal, F. 2018. "Knocking on tax haven's door: Multinational firms and transfer pricing". Review of Economics and Statistics, 100(1), 120-134.

Devereux, Michael P. and John Vella. 2017. "Implications of digitalization for international corporate tax reform." Oxford University Center for Business Taxation Working paper $17 / 07$.

Dharmapala, Dhammika. 2014. "What Do We Know About Base Erosion and Profit Shifting? A Review of the Empirical Literature."” CESIFO Working Paper \#4612.

Dowd, Tim, Paul Landefeld, and Anne Moore. 2017. "Profit Shifting of U.S. Multinationals." Journal of Public Economics, 148: 1-13

EY. 2014. "2014 global transfer pricing tax authority survey" available online at https://www. ey.com/

Haufler, Andreas, Mohammed Mardancd and Dirk Schindler. 2018. "Double tax discrimination to attract FDI and fight profit shifting: The role of CFC rules." Journal of International Economics, 114: 24-43. 
Hebous, S. and Johannesen, N. 2015. "At your service! The role of tax havens in international trade with services".

Heckemeyer, Jost H., and Michael Overesch. 2013. "Multinationals? Profit Response to Tax Differentials: Effect Size and Shifting Channels." ZEW Discussion Papers 13-045.

Hines, James R. Jr and Eric Rice. 1994. "Fiscal Paradise: Foreign Tax Havens and American Business." The Quarterly Journal of Economics, 109(1): 149-182.

Hong, Qing, and Michael Smart. 2010. "In Praise of Tax Havens: International Tax Planning and Foreign Direct Investment." European Economic Review, 54(1): 82-95.

Huizinga, Harry, and Luc Laeven. 2008a. "International profit shifting within multinationals: a multi- country perspective." Journal of Public Economics, vol. 92, 1164-1182.

Huizinga, Harry, Luc Laeven, and Gaetan Nicodeme. 2008b. "Capital Structure and International Debt Shifting," Journal of Financial Economics, 88 (1), 80-118.

Kanbur, Ravi and Keen, Michael. 1993. "Jeux Sans Frontières: Tax Competition and Tax Coordination When Countries Differ in Size." American Economic Review, 83(4): 877-892.

Liu, L., Schmidt-Eisenlohr, T. and Guo, D. 2017. "International transfer pricing and tax avoidance: Evidence from linked trade-tax statistics in the UK." FRB International Finance Discussion Paper, (1214).

Nielsen, S., and P. Raimondos-Moller (2008). 'Taxes and Decision Rights in Multinationals'. Journal of Public Economic Theory, 10(2), 245-58.

Organization for Economic Co-operation and Development. n.d. "OECD MAP Statistics" OECD Publishing. Link

Organization for Economic Co-operation and Development. 2010. "OECD Transfer Pricing Guidelines for Multinational Enterprises and Tax Administrations 2010." OECD Publishing.

Organization for Economic Co-operation and Development. 2015. "Base Erosion and Profit Shifting, Final Report" OECD Publishing.

Organization for Economic Co-operation and Development. 2019a. "Public consultation document Secretariat Proposal for a "Unified Approach" under Pillar One" OECD Publishing.

Organization for Economic Co-operation and Development. 2019b. "Public consultation document Global Anti-Base Erosion Proposal ("GloBE") - Pillar Two" OECD Publishing. PWC. 2017. "Improved dispute solution within the EU regarding double taxation", available online at https://blogg.pwc.se/taxmatters-en/

Slemrod, Joel and John D. Wilson. 2009. "Tax competition with parasitic tax havens." Journal of Public Economics, 93, 1261-1270.

Tørsløv, T.R., Wier, L.S. and Zucman, G. 2018. "The missing profits of nations (No. w24701)". National Bureau of Economic Research.

UNCTAD 2015. "World Investment Report: Reforming International Investment Governance". UNCTAD.

Wier, Ludvig 2020. "Tax-motivated transfer mispricing in South Africa: Direct evidence using transaction data". Journal of Public Economics, (184)

Zucman, Gabriel. 2014. "Taxing Across Borders: Tracking Personal Wealth and Corporate Profits," Journal of Economic Perspectives, 28(4), 121-148. 
Saez, Emmanuel and Zucman, Gabriel. 2019. "The Triumph of Injustice: How The Rich Dodge Taxes and How To Make Them Pay" W.W. Norton $\&$ Company 
Table 1: Danish profit shifting and transfer price corrections per year $(2008,2014,2015)$

Table 1: Danish estimated profit shifting and corrections per year $(2008,2014,2015)$

\begin{tabular}{lccc} 
& {$[1]$} & {$[2]$} & {$[3]$} \\
\hline Panel a: Tax-motivated profit shifting & All countries & Non-tax havens & Tax havens \\
Amounts $€$, Millions) & $\mathbf{2 2 1 5}$ & -455 & 2670 \\
\% of tax base & $\mathbf{6 \%}$ & $-2 \%$ & $8 \%$ \\
\hline Panel b: Transfer price corrections & & & \\
Corrections (\# of cases) & $\mathbf{6 2}$ & 44 & 18 \\
Corrections ( $€$, Millions) & $\mathbf{1 4 5 6}$ & 1190 & 266 \\
Corrections (\% of total) & $\mathbf{1 0 0 \%}$ & $82 \%$ & $18 \%$ \\
\hline Panel $:$ Estimated tax revenue impact ( $€$, Millions) & & & 51 \\
Implied increase in tax revenue in Denmark & $\mathbf{3 1 5}$ & 264 & 10 \\
Implied decrease in tax revenue abroad & $\mathbf{3 3 3}$ & 323 & $\mathbf{4 1}$ \\
Net change in global tax bill if fully realized & $\mathbf{- 1 9}$ & $\mathbf{- 5 9}$ & \\
\hline
\end{tabular}

Notes: This table documents the mismatch between the outcome of Danish transfer pricing cases and the estimated direction of tax-motivated profit shifting. Panel a: Reports the estimated intentional and systematic tax-motivated profit shifting - a negative number suggests that Denmark is a net recipient of profits. Tax motivated profit shifting between non tax havens is based on Alvarez-Martinez et al. (2018) - because Denmark is a moderately low-taxed country, the estimates suggests that Denmark is a net-recipient of tax-motivated profit shifting from non-tax havens. Tax motivated profit shifting between non tax havens is based on Tørsløv et al. (2018). Panel b: Reports the outcome of the Danish tax authorities prosecution of transfer pricing cases. Panel c: Reports the ultimate impact on tax collection of the Danish transfer price corrections in Denmark and abroad (assuming that the corrections are not overturned in court and that dispute resolution is effective). Source: Danish Inland Revenue, Alvarez-Martinez et al. 2018, Tørsløv et al. (2018), KPMG (2018), Author calculations (see text) 


\section{Figure 1: Private vs public employment in transfer pricing}

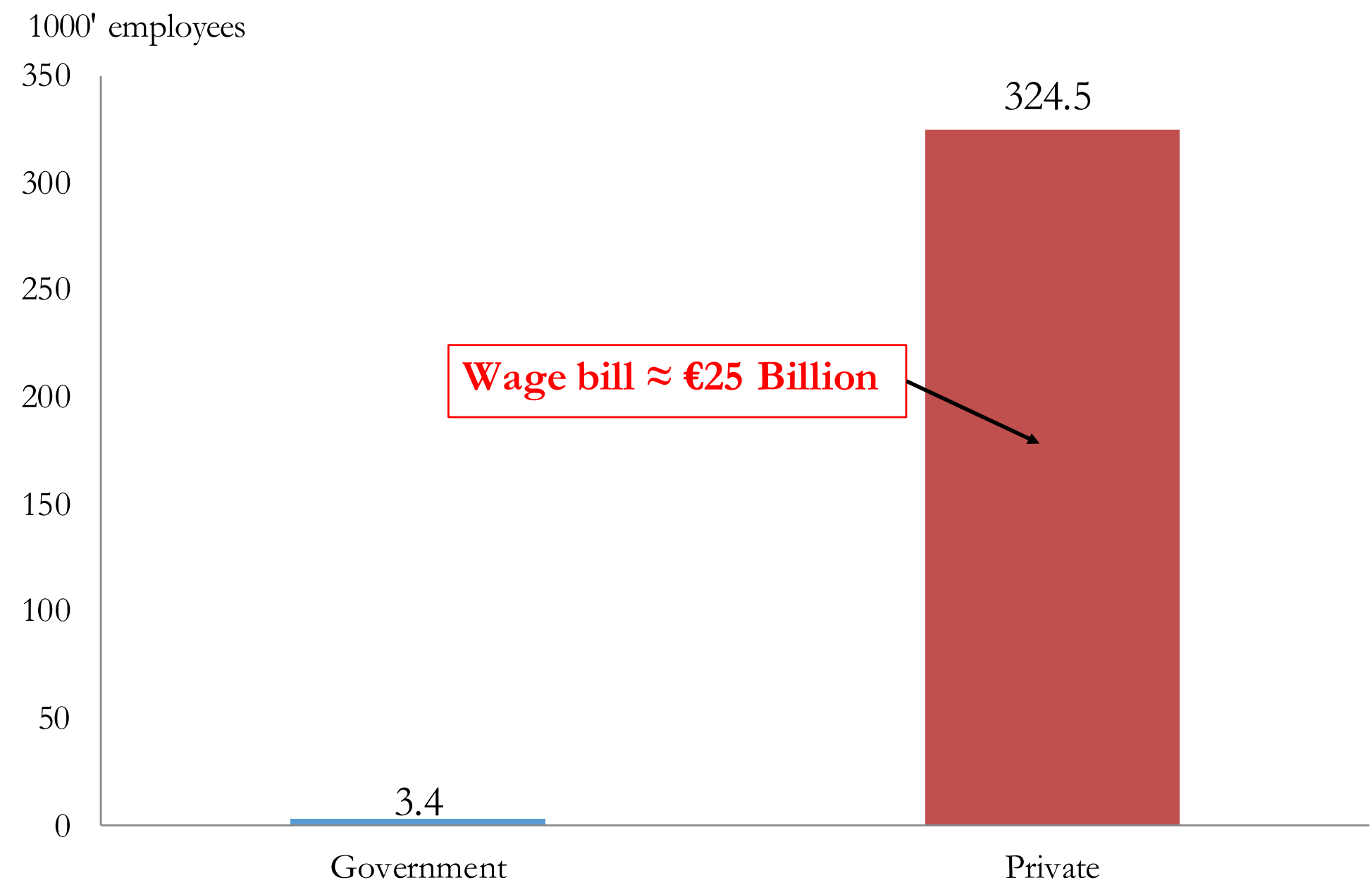

Notes: This figure shows the share of transfer pricing specialists working in the public and private sector. 328,261 is the number of individuals that LinkedIn highlights when searching "transfer pricing" under "people" (as of January 4, 2020). Spot checks confirm that LinkedIn correctly identifies individuals working with transfer pricing. The number of individuals working in government with transfer pricing is first identified by filtering the search by industry to "government adminstration" only (3,368 as of January 4, 2020) and corroborated by the head count in EY's Transfer Pricing Tax Authority Survey from 2014. The Wage bill is estimated using the average base salary of a transfer pricing specialist ( $\$ 74,000$ as of Jan 4 , 2020) computed by Glassdoor. Source: Author computations based on LinkedIn, EY and Glassdoor data 


\section{Figure 2: Tax differentials in transfer price corrections versus in the full population}

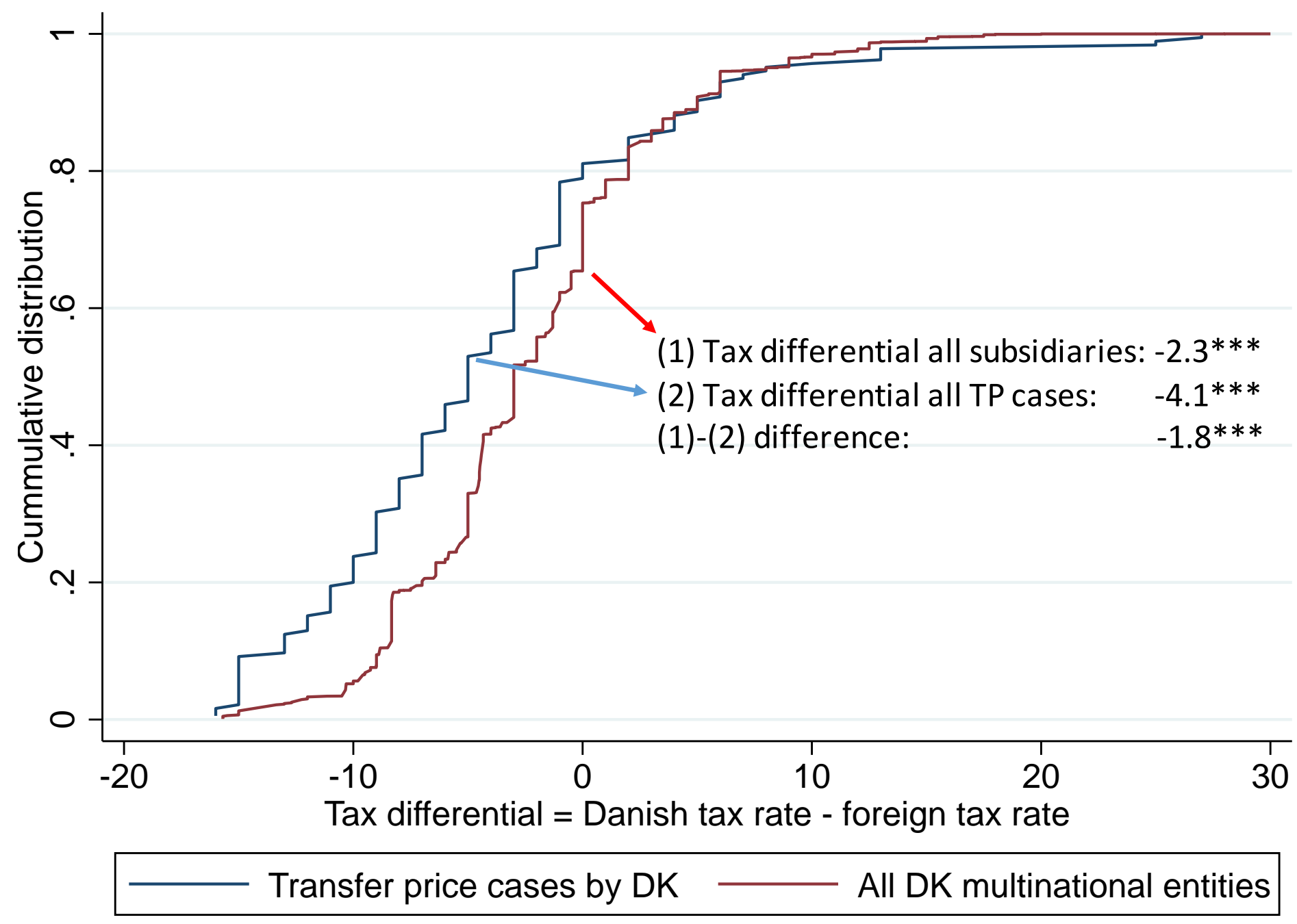

Notes: This figure shows the cumulative distribution of the tax differentials across all Danish transfer pricing cases and across all Danish vis-a-vis foreign firm linkages. The tax differential is defined as the Danish corporate tax rate less the counterpart country tax rate. Tax rates are from KPMG (2018). The blue line shows the distribution of tax differentials in all transfer price corrections in 2008, 2014 and 2015. The red line shows the tax differential between all Danish multinational entities (subsidiaries and parents) and their foreign related parties. Source: Danish Inland Revenue, Tørsløv et al. (2018), KPMG (2018), and authors' computations (see text) 


\section{Figure 3: The multinational firm fighting back... when it suits them}

\section{Tax differential across court cases}

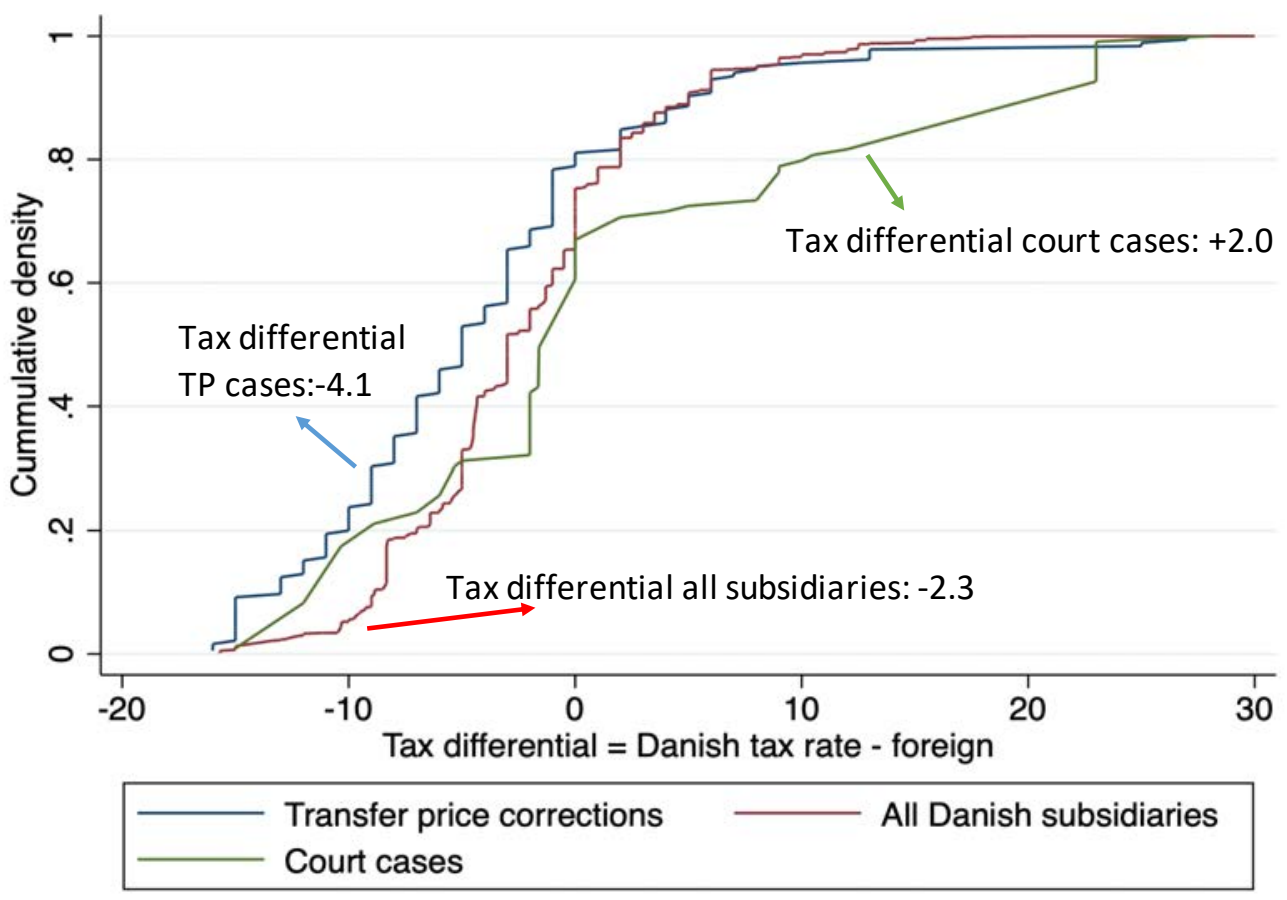

Tax differential across court cases (excl. cases with low MAP opportunity)

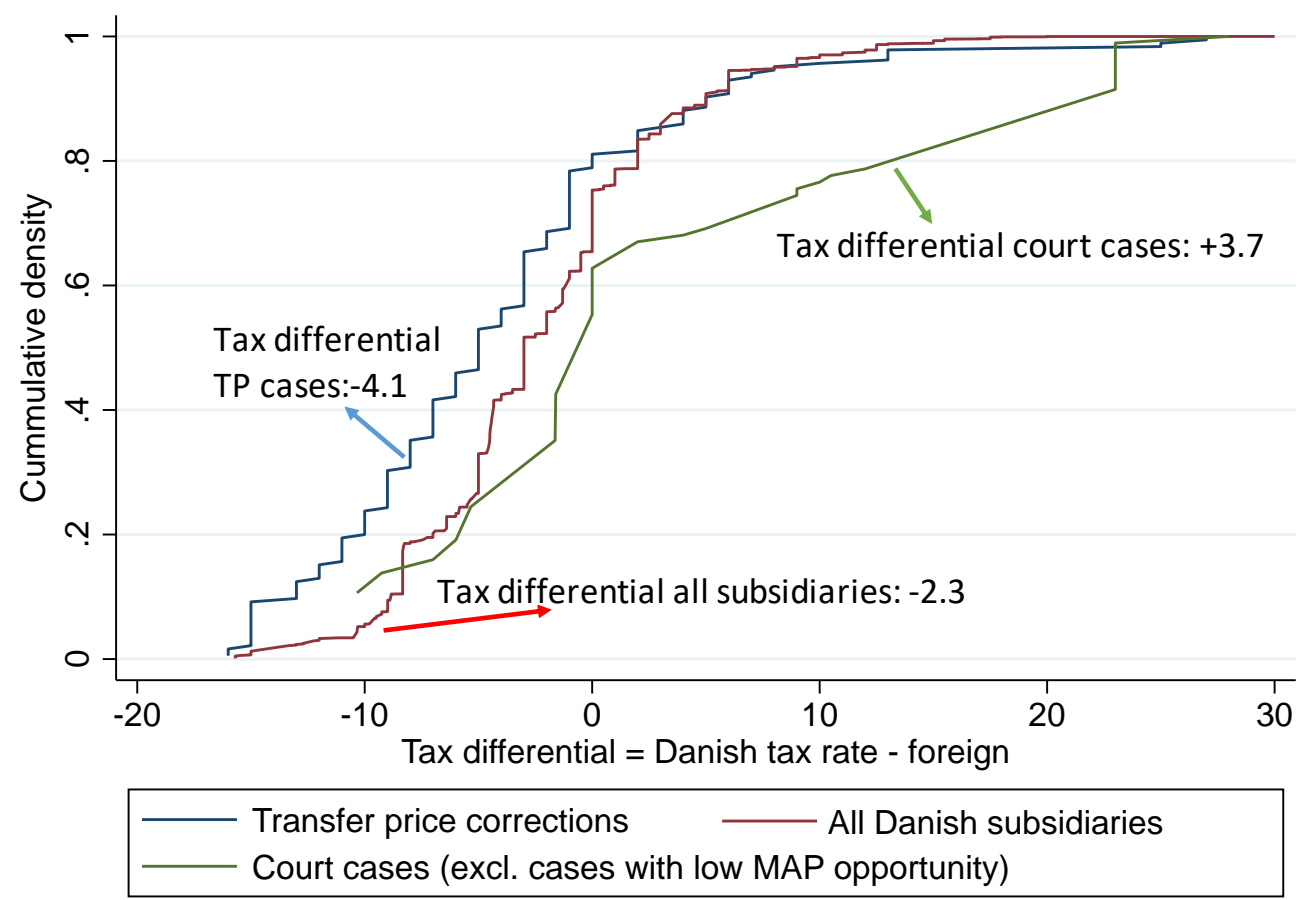

Note: This figure shows the cumulative distribution of the tax differentials across court cases where the firm objects to a correction. The tax differential is defined as the Danish corporate tax rate less the counterpart country tax rate. The red line shows the tax differential between all Danish multinational entities (subsidiaries and parents) and their foreign related parties. The green line shows the tax differentials across court cases where the firm objects to a correction (the top panel includes all cases while the bottom panel includes only cases involving EU countries where the likelihood of dispute settlement is larger). Source: Danish Inland Revenue, Tørsløv et al. (2018), KPMG (2018), and authors' computations (see text) 


\section{Figure 4: Global top targets in transfer price corrections}
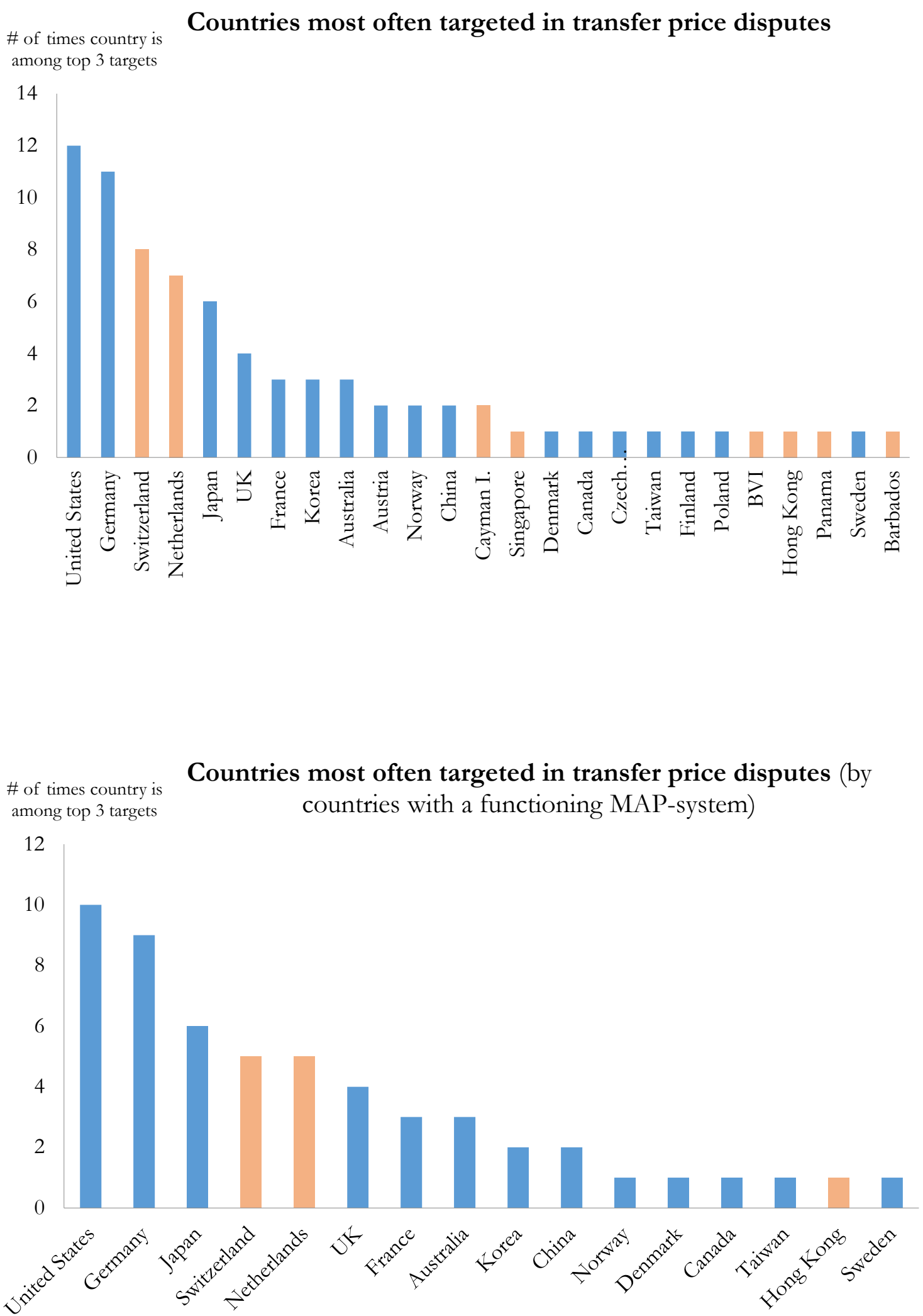

Notes: The top panel shows the most frequently cited top-3 targets in transfer price correction cases among 26 major economies surveyed by EY in 2014. The bottom panel restricts the sample of surveyed countries to those with a functioning mutual agreement procedure in place. Tax havens are defined as in Tørsløv et al. (2018) and marked in orange. Source: EY (2014), Author calculations (see text) 
Figure 5: Mutual agreement procedures in the EU

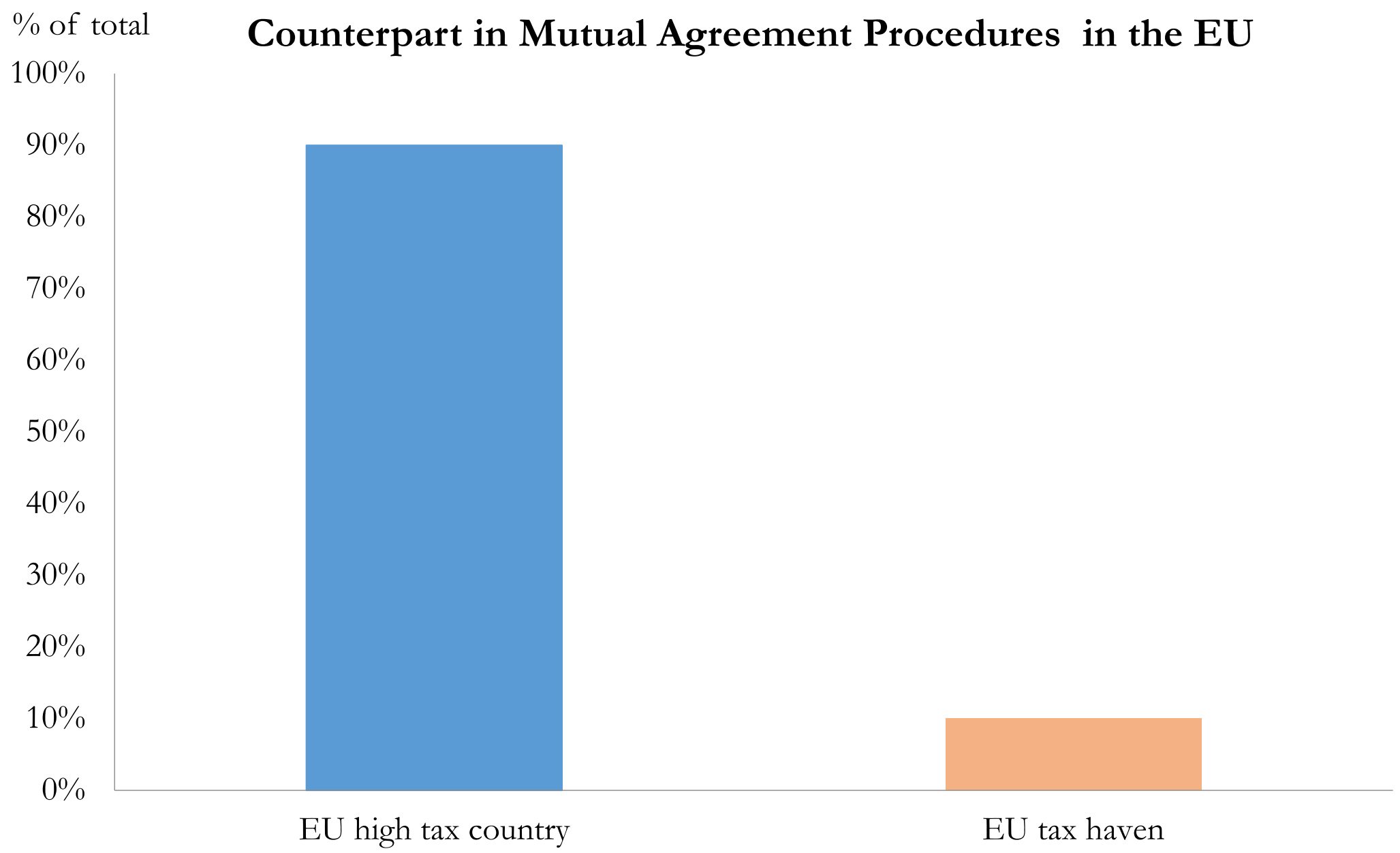

Notes: The graph shows the counterpart in EU mutual agreement procedures initiated by an EU high-tax country with Arbitrage Convention invoked meaning these are cases where disputes have to be settled within 2 years. EU tax havens are defined as in Tørsløv et al. (2018). Source: EU joint transfer pricing forum, Tørsløv et al. (2018) 
Figure 6: Mutual agreement procedures globally

Target country mutual agreement procedure (closed cases, 2018)

250

200

Share of procedures with tax haven as target: $8 \%$

150

100

Share of procedures with high-tax country as target: $92 \%$

50

0

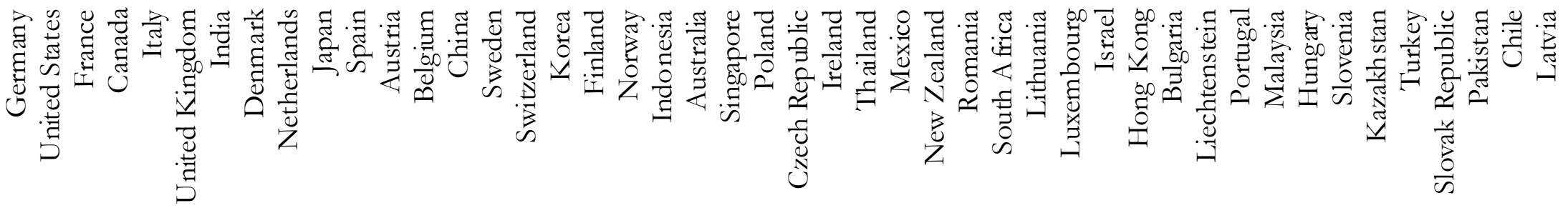

Notes: The graph shows the target of mutual agreement procedures following transfer price corrections in the 137 member countries of the OECD inclusive framework. Countries reporting zero mutual agreement procedures are left out of the chart. Tax havens are marked in red using the definition from Tørsløv et al. (2018). Source: OECD MAP statistics 
Appendix figures 


\section{Figure A1: Tax differentials in transfer price corrections versus in the full population}

Tax differential across mutual agreement procedures

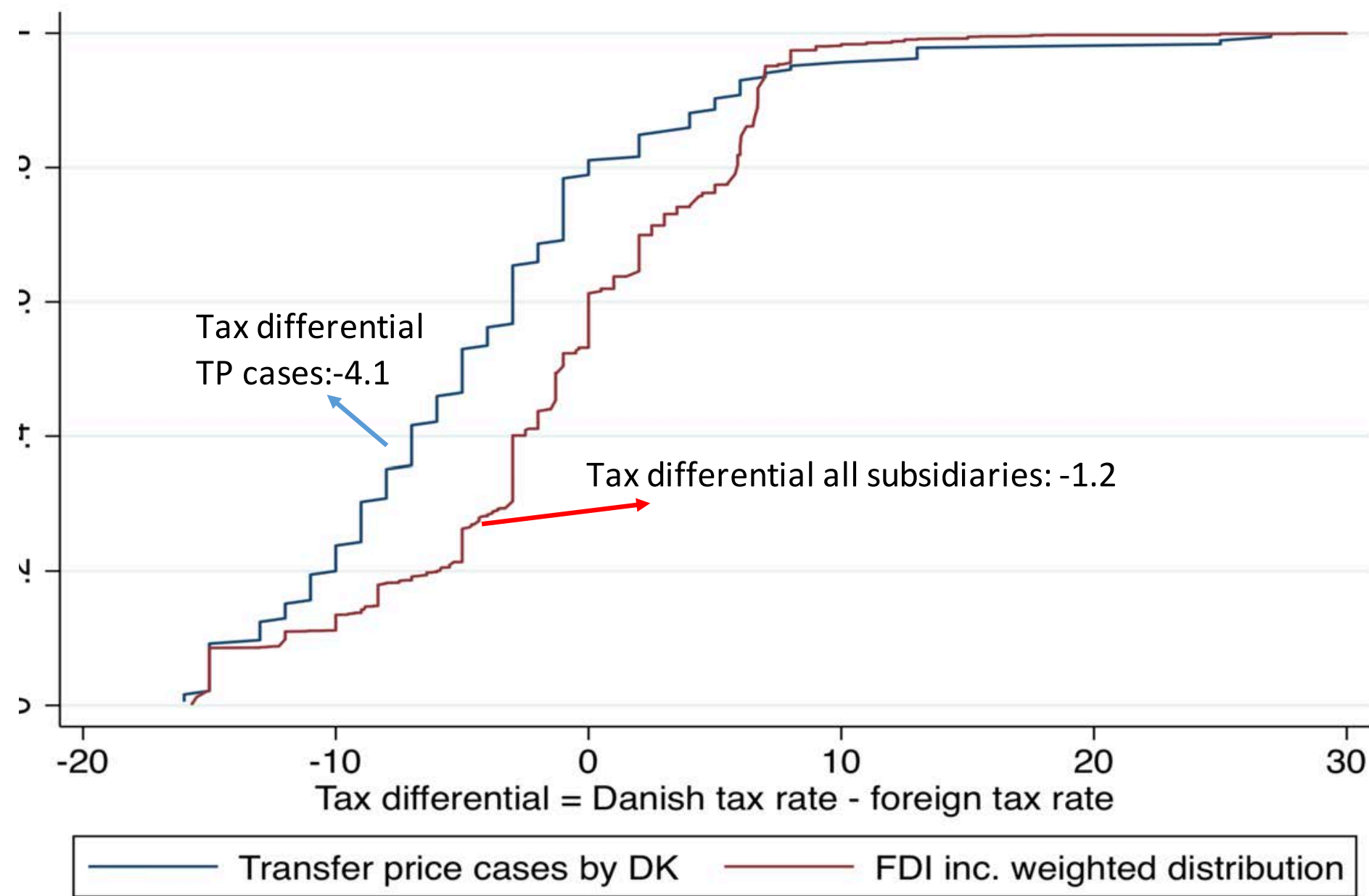

Notes: This figure shows the cumulative distribution of the tax differentials across all Danish transfer pricing cases and across all Danish vis-a-vis foreign firm linkages. The tax differential is defined as the Danish corporate tax rate less the counterpart country tax rate. Tax rates are from KPMG (2018). The blue line shows the distribution of tax differentials in all transfer price corrections in 2008, 2014 and 2015. The red line shows the tax differential between between Denmark and all foreign countries weighted according to total (inward and outward) FDI income in 2015. Source: Danish Inland Revenue, Tørsløv et al. (2018), KPMG (2018), Eurostat table "bop fdi6 inc" and authors' computations (see text) 
Figure A2: Tax differentials in transfer price corrections versus in the full population

Tax differential across mutual agreement procedures

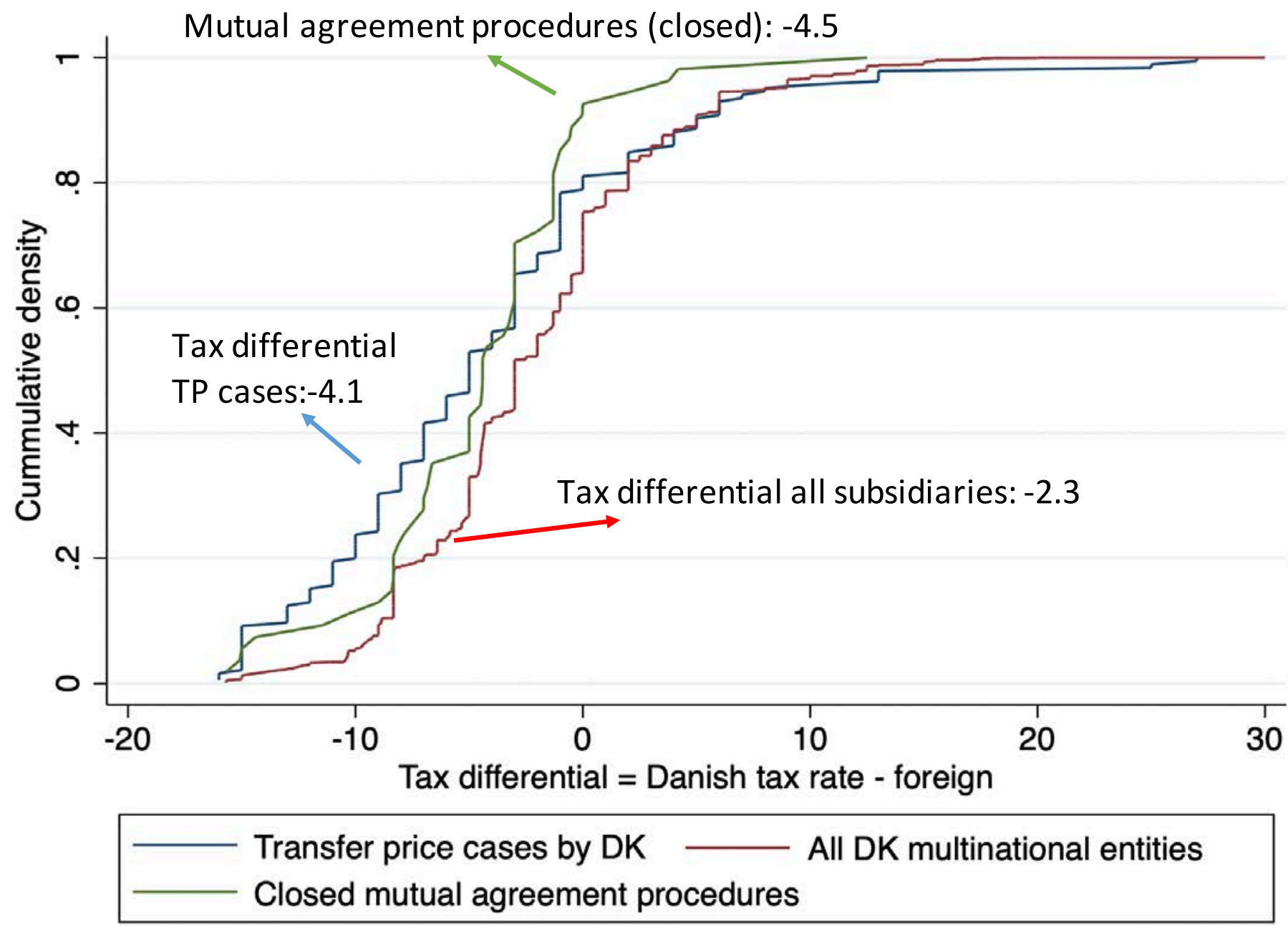

Notes: This figure shows the cumulative distribution of the tax differentials across all closed (completed and non-zero) mutual agreement procedures 20082015 (green line). This distribution is contrasted to the distribution of danish transfer pricing cases (blue line) and across all Danish vis-a-vis foreign firm linkages (red line). The tax differential is defined as the Danish corporate tax rate less the counterpart country tax rate. Tax rates are from KPMG (2018). The blue line shows the distribution of tax differentials in all transfer price corrections in 2008, 2014 and 2015. The red line shows the tax differential between all Danish multinational entities (subsidiaries and parents) and their foreign related parties. Source: Danish Inland Revenue, Tørsløv et al. (2018), KPMG (2018), and authors' computations (see text) 
Figure A3: New mutual agreement procedures globally following BEPS

\section{Increase in mutual agreement cases started from 2016 to 2018}

100

90

80

70

60

50

40

30

20

10

0

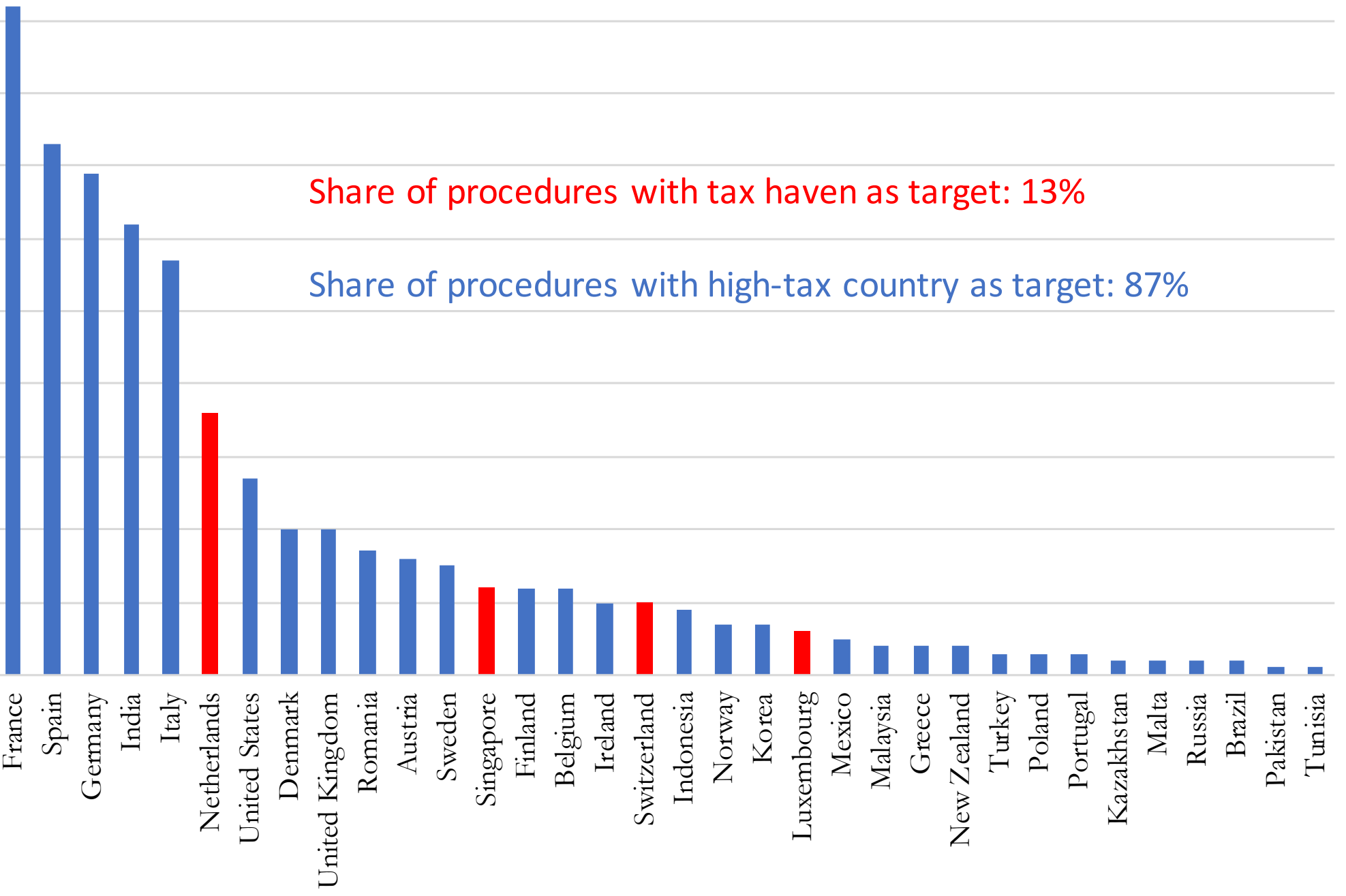

Notes: The graph shows the target of mutual agreement procedures following transfer price corrections in the 137 member countries of the OECD inclusive framework. Countries reporting zero mutual agreement procedures are left out of the chart. Tax havens are marked in red using the definition from Tørsløv et al. (2018). Source: OECD MAP statistics 